Baliatsas, C., Bolte, J., Yzermans, J., Kelfkens, G., Hooiveld, M., Lebret, E., Kamp, I. van. Actuałh and perceived exposure to electromagnetic fields and non-specific physical symptoms: an epidemiological study based on self-reported data and electronic medical records. Internationaly Journal of Hygiene and Environmental Health: 2015

\begin{tabular}{l|l}
$\begin{array}{l}\text { Postprint } \\
\text { Version }\end{array}$ & 1.0 \\
\hline Journal website & http://www.sciencedirect.com/science/article/pii/S1438463915000188 \\
\hline Pubmed link & $\underline{\text { http://www.ncbi.nlm.nih.gov/pubmed/?term=25704188 }}$ \\
\hline DOI & $10.1016 /$ j.jiheh.2015.02.001
\end{tabular}

This is a NIVEL certified Post Print, more info at http://www.nivel.eu

\title{
Actual and perceived exposure to electromagnetic fields and non-specific physical symptoms: An epidemiological study based on self-reported data and electronic medical records
}

\author{
CHRistos BALIATSAS ${ }^{\text {, B, , , JOHN BOLTE }}{ }^{\mathrm{B}}$, JORIS YZERMANS ${ }^{\mathrm{C}}$, GERT KELFKENS ${ }^{\mathrm{B}}$, MARIETTE \\ HOOIVELD $^{\mathrm{C}}$, ERIK LEBRET ${ }^{\mathrm{A}, \mathrm{B}}$, IRENE VAN KAMP ${ }^{\mathrm{B}}$
}

\begin{abstract}
Background: There is continuing scientific debate and increasing public concern regarding the possible effects of electromagnetic fields (EMF) on general population's health. To date, no epidemiological study has investigated the possible association between actual and perceived EMF exposure and nonspecific physical symptoms (NSPS) and sleep quality, using both self-reported and general practice (GP)-registered data.

Methods: A health survey of adult $(\geq 18)$ participants $(n=5933)$ in the Netherlands was combined with the electronic medical records (EMRs) of NSPS as registered by general practitioners. Characterization of actual exposure was based on several proxies, such as prediction models of radiofrequency (RF)EMF exposure, geo-coded distance to high-voltage overhead power lines and self-reported use/distance of/to indoor electrical appliances. Perceived exposure and the role of psychological variables were also examined.

Results: Perceived exposure had a poor correlation with the actual exposure estimates. No significant association was found between modeled RF-EMF exposure and the investigated outcomes. Associations with NSPS were observed for use of an electric blanket and close distance to an electric charger during sleep. Perceived exposure, perceived control and avoidance behavior were associated with the examined outcomes. The association between perceived exposure was stronger for self-reported than for GP-registered NSPS. There was some indication, but no consistent pattern for an interaction between idiopathic environmental intolerance (IEI-EMF) and the association between actual exposure and NSPS.

Conclusions: In conclusion, there is no convincing evidence for an association between everyday life RF-EMF exposure and NSPS and sleep quality in the population. Better exposure characterization, in particular with respect to
\end{abstract}


Baliatsas, C., Bolte, J., Yzermans, J., Kelfkens, G., Hooiveld, M., Lebret, E., Kamp, I. van. Actuah and perceived exposure to electromagnetic fields and non-specific physical symptoms: an epidemiological study based on self-reported data and electronic medical records. International Journal of Hygiene and Environmental Health: 2015

sources of extremely low frequency magnetic fields (ELF-MF) is needed to draw more solid conclusions. We argue that perceived exposure is an independent determinant of NSPS.

\section{Abbreviations}

- EMF, electromagnetic fields;

- RF-EMF, radiofrequency EMF;

- ELF-MF, extremely low-frequency magnetic field;

- NSPS, non-specific physical symptoms;

- IEI-EMF, idiopathic environmental intolerance attributed to EMF;

- GP, general practice

\section{INTRODUCTION}

The extensive use of mobile phone devices and associated communication systems and the increasing installation of mobile phone base stations and high-voltage overhead power lines has led to public concern and continuing scientific debate regarding the potential health effects of exposure to electromagnetic fields (EMF) in the general population (Kowall et al., 2012). Recently, the International Agency for Research on Cancer (IARC) classified exposure to radiofrequency (RF) EMF as "possibly carcinogenic" (Baan et al., 2011) and there is evidence that extremely low frequency magnetic field (ELF-MF) may be associated with childhood leukemia (Zhao et al., 2014).

In addition to these diagnosed medical conditions, also a broad range of symptoms has been suspected to be associated with EMF, such as headache, fatigue, dizziness, sleep problems, ear symptoms and skin sensations (Genuis and Lipp, 2011). Selfreported (hyper)sensitivity and/or attribution of such symptoms to EMF sources, has been described by the WHO as idiopathic environmental intolerance attributed to EMF (IEI-EMF) (Baliatsas et al., 2012a and Hillert et al., 2006). Recent evidence from experimental and observational studies consistently suggests that there is no convincing evidence for an association between such symptoms and related physiologic reactions and exposure to EMF (Augner et al., 2012, Baliatsas et al., 2012b, Leitgeb, 2012, Röösli et al., 2010a, Rubin et al., 2010 and Rubin et al., 2011). Since the cause of these complaints seems to be unclear, they are often referred to as “Medically Unexplained (Physical) Symptoms” (MUPS) (van den Berg, 2007) or alternatively, "Non-specific (Physical) Symptoms” (NSPS) (Baliatsas et al., 2011 and Baliatsas et al., 2014).

The current methodological challenges in this research field denote that there is still scope for better research, especially in the epidemiological domain (Baliatsas and Rubin, 2014). While experimental ("provocation”) studies can assess only short-term exposure and effects in small population subgroups, epidemiological studies fill this gap by allowing for the investigation of long-term exposure and outcomes in large samples under normal living conditions. However, exposure characterization remains a major challenge.

Exposure in daily life occurs from far-field sources (e.g. fixed transmitters for radio and television and mobile phone base stations) as well as from an array of near-field sources (e.g. DECT telephones and wireless networks). All these contribute to an individuals' personal exposure to a varying degree depending on proximity, source type, source usage and a number of other contextual parameters (Frei et al., 2010). 
Baliatsas, C., Bolte, J., Yzermans, J., Kelfkens, G., Hooiveld, M., Lebret, E., Kamp, I. van. Actuah and perceived exposure to electromagnetic fields and non-specific physical symptoms: an epidemiological study based on self-reported data and electronic medical records. International7 Journal of Hygiene and Environmental Health: 2015

On the one hand, assessment of exposure that relies exclusively on self-report leads to severe misclassification (Frei et al., 2010, Hutter et al., 2012, Inyang et al., 2008 and Shum et al., 2011) and should rather be used as an indicator of the individual perception of being exposed (Baliatsas et al., 2012b and Röösli, 2008). On the other hand, only a limited number of epidemiological studies has used methodologically advanced proxies of actual field strength such as spot measurements, personal exposimeters and prediction modeling (Röösli et al., 2010a and Baliatsas et al., 2012b). Still, these approaches are also not free of limitations.

For example, spot measurements provide information only on exposure for specific locations at specific (typically short) times (Frei et al., 2010); personal exposure measurements, although more advanced as a surrogate, are costly, labor-intensive and prone to shortcomings related to e.g. calibration, and body shielding (Bolte et al., 2011 and Mann, 2010). It is also unclear whether the use of personal exposure monitors may bias response and systematically alter participants' exposure-related behavior and/or their tendency to perceive exposure. Furthermore, the association between ELF-MF exposure and NSPS in the population has been scarcely investigated (Baliatsas and Rubin, 2014). Bearing these methodological issues in mind and the fact that a biological mechanism for NSPS in relation to EMF is unknown, it is of importance to take into account exposure from all relevant sources (Frei et al., 2012). A prediction model based on modeled exposure from fixed transmitters and exposure-relevant activities may be the best compromise in terms of both adequate characterization and cost-effectiveness (Bolte et al., 2011).

Proper outcome assessment is also a fundamental and still challenging part of research on EMF and NSPS, since the cut-off points for considering a symptom as present or severe vary across studies and it is unknown whether they can be of clinical relevance (Baliatsas et al., 2012b and Baliatsas et al., 2014). The use of data based on symptoms registered in electronic medical records (EMR) of general practices (GP) overcomes such disadvantages and facilitates the comparability of outcome assessment between studies (van den Berg, 2007). Assessment based on symptom scores can be a sound approach, given the possibly large variation of physiological reactions to EMF, if a bioelectromagnetic mechanism exists (Tuengler and von Klitzing, 2013) and considering that scores on symptom number and duration are consistent indicators of severity in environmentally sensitive people and the broader population (Baliatsas et al., 2014 and van den Berg et al., 2005). In addition to research on the possible association between actual EMF exposure levels and NSPS in the population, it is also important to explore the psychological framework through which symptoms may occur, expanding the standard risk-factor approach. A strong body of evidence from experimental studies suggests that NSPS can occur when people believe they are exposed, irrespective of whether their belief is accurate or not (Röösli, 2008, Röösli et al., 2010a, Rubin et al., 2010 and Szemerszky et al., 2010). It has been suggested that this could indicate a so-called "nocebo" effect, in which the perception of exposure triggers a selffulfilling expectation of symptom occurrence (Rubin et al., 2010 and Szemerszky et al., 2010).

A number of studies have also emphasized the predictive value of psychological factors in the report of NSPS attributed to EMF, such as environmental worries, dysfunctional cognitions, avoidance of exposure as a strategy to cope with the 
Baliatsas, C., Bolte, J., Yzermans, J., Kelfkens, G., Hooiveld, M., Lebret, E., Kamp, I. van. Actuah and perceived exposure to electromagnetic fields and non-specific physical symptoms: an epidemiological study based on self-reported data and electronic medical records. Internationaly Journal of Hygiene and Environmental Health: 2015

perceived environmental stressor, anxiety, depression, and increased body awareness and somatosensory amplification (Frick et al., 2002, Johansson et al., 2010, Koteles et al., 2011, Landgrebe et al., 2008, Nordin et al., 2010, Rubin et al., 2008 and Witthöft and Rubin, 2013). These seem to be conceptually in line with a generic mechanism of environmental stress (Lazarus and Folkman, 1984 and van Kamp, 1990) and more recent cognitive and behavioral models elaborating on medically unexplained symptoms (Rief and Broadbent, 2007 and Witthöft and Rubin, 2013). However, the majority of these studies have been focusing on small samples of environmentally sensitive subgroups and in many cases, actual exposure was not considered. In contrast, there is limited knowledge on the role of perceived exposure and potentially relevant psychological variables such as perceived control and coping, in EMF epidemiology (Baliatsas et al., 2011 and Baliatsas et al., 2012b). Although a few recent studies (Frei et al., 2012, Heinrich et al., 2011, Mohler et al., 2010 and Mohler et al., 2012) included variables such as environmental worries, these were solely treated as confounders.

Finally, although people with IEI-EMF experience poorer health, increased illness behavior and more severe NSPS compared to non-sensitive individuals (Baliatsas et al., 2014), very limited evidence exists on the moderating role of IEI-EMF on the association between symptomatology and actual and perceived exposure (Röösli et al., 2010b).

The investigation of the predicting and moderating role of perceived exposure and psychological variables, taking objective exposure estimates into account, could add further to the knowledge about potential determinants of NSPS within the context of environmental health. The current study therefore adopts a multidisciplinary approach on exposure characterization and outcome assessment, investigating proxies of RF-EMF and ELF-MF as well as perceived exposure in relation to both self-reported and GP-registered data. Furthermore, it makes a first step toward the investigation of the potential role of psychological variables in symptom report. The main research questions addressed were: (1) What is the association between self-reported and GP-registered NSPS and actual and perceived exposure to EMF in the population and potentially susceptible subgroups? (2) Are psychological factors such as perceived control and coping behavior related to NSPS? and (3) Is there a moderating role of psychological variables on the association between perceived exposure and NSPS?

\section{METHODS}

\section{Study design and participants}

The present study was performed within the framework of the "EMPHASIS" project ("Non-specific physical symptoms in relation to actual and perceived exposure to EMF and the underlying mechanisms"), which combined two data collection methods: A cross-sectional survey $(n=5933$, participation rate $46 \%)$ using a selfadministered questionnaire entitled "Living environment, technology and health" and electronic medical records (EMRs) of health problems and medication prescriptions, as registered by general practitioners. The selection of general practices was made from the primary care database of the Netherlands Institute for Health Services Research (NIVEL).

As shown in Fig. 1, preliminary assessment of residential exposure to mobile phone base stations was an integral part of the study design: During the sampling process, 
Baliatsas, C., Bolte, J., Yzermans, J., Kelfkens, G., Hooiveld, M., Lebret, E., Kamp, I. van. Actuah and perceived exposure to electromagnetic fields and non-specific physical symptoms: an epidemiological study based on self-reported data and electronic medical records. Internationaly Journal of Hygiene and Environmental Health: 2015

the antenna data and the pool of eligible addresses were imported into the geographic information system (GIS-EMF) operated by the Netherlands National Institute for Public Health and the Environment (RIVM); data reflected the situation at the time of the performance of the study (2011). For every address, all antennas within a radius of $500 \mathrm{~m}$ were selected and the power density produced by each base station at the address location was calculated (Kelfkens et al., 2012, Neitzke et al., 2005 and Neitzke et al., 2007). Based on these preliminary estimates, the sample pool was stratified per exposure category (low, medium, high); higher exposure categories were oversampled in order to enhance exposure contrast among participants (Kelfkens et al., 2012).

\section{[FIGURE 1]}

From each household only one adult was randomly sampled. The survey questionnaire consisted of four sections: (1) Residential environment, (2) Health, (3) Well-being and (4) Household and demographic information. Potential participants were not informed that the study focused on EMF and the questions on health outcomes preceded questions relevant for exposure assessment. The privacy regulation of the study was approved by the Dutch Data Protection Authority. Based on the Law on Medical Scientific Research (WMO), the Dutch Medical Ethics Committee decided that an ethical approval was not required.

Additional information on the study sample and survey procedure has been described in more detail elsewhere (Baliatsas et al., 2014).

\section{Characterization of actual EMF exposure}

The characterization of actual exposure used a combination of information from different origin, to combine contributions from far-field and near-field sources to personal exposure. As described in the previous section, categorization into exposure percentiles based on preliminary estimates of RF-EMF from mobile phone base stations was one of the criteria used to select the study population.

In the second stage, additional information was obtained from the survey questionnaire in order to calculate the full model of exposure to base stations. This information concerned the orientation of the dwelling and building characteristics such as the properties of the walls and windows (Kelfkens et al., 2012 and Neitzke et al., 2007). The exposure model was built based on the approach of the ECOLOG institute (Neitzke et al., 2005 and Neitzke et al., 2007), in which the average RFEMF exposure at home emitted from mobile phone base stations (GSM900, GSM1800) was estimated. Additional details regarding the calculation of the ECOLOG model in the present study have been described elsewhere (Kelfkens et al., 2012).

Furthermore, a list of questions on exposure-relevant activities was included in the survey. The selection of these activities was based on models from the Activity Exposure Matrix (AEM) (Bolte et al., 2008 and Bolte et al., 2013); this was developed in an external exposimeter study in the Netherlands. In this study, personal exposure to 12 bands of environmental RF-EMF on the power flux density scale in $\mathrm{mW} / \mathrm{m}^{2}$ was modeled (Bolte and Eikelboom, 2012): FM radio (frequency modulation; 88-108 MHz), TV3 (television; 174-233 MHz), TETRA (terrestrial trunked radio used by emergency services; 380-400 MHz), TV4\&5 (470-830 MHz), GSM uplink (global system for mobile communications; 880-915 MHz), GSM downlink (925-960 MHz), GSM1800 (or DCS) uplink (digital cellular service; 
Baliatsas, C., Bolte, J., Yzermans, J., Kelfkens, G., Hooiveld, M., Lebret, E., Kamp, I. van. Actuah and perceived exposure to electromagnetic fields and non-specific physical symptoms: an epidemiological study based on self-reported data and electronic medical records. International Journal of Hygiene and Environmental Health: 2015

1710-1785 MHz), GSM1800 downlink (1805-1880 MHz), DECT (digital enhanced cordless telecommunication; 1880-1900 MHz), UMTS uplink (universal mobile telecommunication system; 1920-1980 MHz), UMTS downlink (2110-2170 MHz), WiFi (wireless Internet; 2400-2500 MHz). TV3 and TV4\&5 were originally the bands for analog TV broadcasts. However, in the Netherlands all broadcasts are Digital Video Broadcasting Terrestrial (DVB-T) in the TV4\&5 frequency band. Also part of the radio broadcasts are Terrestrial Digital Audio Broadcasting (T-DAB) at 174-230 MHz in the TV3 band.

Based on the ECOLOG estimation and the models from the AEM study each participant received an exposure predictor based on multivariable non-linear regression models. Six prediction models of individual exposure to RF-EMF were developed, corresponding to different frequency bands. The following exposurerelevant parameters (Bolte and Eikelboom, 2012) were selected for each prediction model:

1. GSM900 base stations (explained variance $R^{2}=0.27$ ): Hours per week spending at large public transport stations, hours per week traveling with a car, hours per week walking outdoors, white collar occupation indoors and at home exposure from GSM900 computed by the ECOLOG model.

2. GSM1800 base stations $\left(R^{2}=0.15\right)$ : Hours per week spending at large public transport stations, hours per week traveling with a car and at home exposure from GSM1800 base stations, based on the ECOLOG model.

3. DECT $\left(R^{2}=0.26\right)$ : Type of residency and owning a DECT phone at home.

4. Uplink (exposure from mobile phone use by bystanders, $R^{2}=0.27$ ): Outdoor blue collar occupation, hours per week traveling with a car, hours per week spending at a pub/café/disco/snack bar and hours per week relaxing outside.

5. Downlink (cumulative exposure from base stations, $R^{2}=0.27$ ): Hours per week spending at large public transport stations, hours per week traveling with a car, hours per week and at home exposure from GSM900 and GSM1800 mobile phone base stations computed by the ECOLOG model.

6. Ratio/TV $(\mathrm{RTV})\left(R^{2}=0.18\right)$ : Hours per week spending at large public transport stations and indoor blue collar occupation in industry.

The models for ELF exposure yielded less satisfactory results, with lower explained variance than for RF. Therefore, proxies of ELF exposure were not quantified based on modeled personal exposure, but on more qualitative information about ownership, use and proximity of sources. More specifically, the addresses of the $n=5993$ final respondents were imported into the geographic information system operated by RIVM, which contains a layer with the location and voltage level of the overhead power lines in the Netherlands. For every respondent, the distance to the closest power line was calculated. The overhead high-voltage power lines have five voltage levels ranging from $50 \mathrm{kV}$ to $380 \mathrm{kV}$. In the analysis, distance to power lines was treated as dichotomous variable ( $\leq 200 \mathrm{~m}$ vs. $>200 \mathrm{~m}$ ).

Finally, self-reported use of indoor electrical appliances was assessed. Selection was based on being commonly used in the population, the potential contribution to total magnetic field exposure as documented in technical papers (Leitgeb et al., 2007 and Mezei et al., 2001), literature reports on attribution of symptoms by potentially susceptible population subgroups (Baliatsas et al., 2012a and Hagström et al., 2013) and previous epidemiological studies investigating associated health effects (Chen et al., 2013, Kleinerman et al., 2005 and Zheng et al., 2000). Questions 
Baliatsas, C., Bolte, J., Yzermans, J., Kelfkens, G., Hooiveld, M., Lebret, E., Kamp, I. van. Actuah and perceived exposure to electromagnetic fields and non-specific physical symptoms: an epidemiological study based on self-reported data and electronic medical records. Internationalf Journal of Hygiene and Environmental Health: 2015

on the following appliances were included in the survey questionnaire: Electric alarm clock, electric charger, electric oven, induction hob, electric/ceramic hob, personal computer (PC) or laptop, electric blanket and vacuum cleaner. Participants were asked whether they were making use of the examined appliances at home or work. The questions on the position of electric charger and alarm clock were categorized according to distance from head during sleep ( $\leq 50 \mathrm{~cm}$ vs. $>50 \mathrm{~cm}$ ).

\section{Assessment of perceived exposure to EMF}

This was based on the question "To what extent do you think you are exposed to electromagnetic fields?” referring to three situations: (1) at home, (2) at work, (3) outdoors. Items were highly inter-correlated (Spearman's rho $=0.7$, internal consistency Cronbach's $a=0.87$ ).

Responses for each situation were scored on an 11-point scale ranging from "not at all" to "very much". A higher sum score on the three items represents higher (generalized) perceived exposure to EMF.

\section{Assessment of self-reported outcomes}

Twenty-three items from the Symptoms and Perceptions (SaP) scale (Baliatsas et al., 2014 and Yzermans et al., 2012) were used to assess the number ("in the past month") and duration of NSPS. Selected items correspond to symptoms in different organ systems that frequently labeled as "unexplained"; a higher sum score on the subscales "number of NSPS" and "duration of NSPS" indicates increased symptom report and longer duration.

Sleep quality was measured on a 10-item scale (Visser et al., 1978); a higher score indicates more sleep problems/lower sleep quality.

\section{Assessment of GP-registered outcomes}

Non-specific physical symptoms in EMRs were registered by the general practitioners based on the international classification of primary care (ICPC) (Lamberts and Wood, 1987). The assessment of practitioner's clinical evaluation of the symptoms was based on "episodes of care" (WONCA, 1995).

An episode was identified as "non-specific" if there was no registered medical diagnosis as an explanation for the symptoms, during the year before the study. Registered NSPS which corresponded with the 23 symptoms from the self-reported questionnaire we selected. For instance, the symptom "sleep problems" corresponded to the ICPC code P06 ("sleep disturbance"). More details regarding the assessment of the self-reported and GP-registered outcomes are presented in a previous publication (Baliatsas et al., 2014).

\section{Idiopathic environmental intolerance attributed to EMF (IEI-EMF)}

The case definition for IEI-EMF was based on the dominant criteria in the peerreviewed literature (Baliatsas et al., 2012a). People who reported "quite agree” or "strongly agree" on the statements: "I am sensitive to mobile phone base stations and devices related to communication systems" and "I am sensitive to electrical devices", were defined as the IEI-EMF group.

\section{Psychological variables}

Perceived control was assessed with three items (Baliatsas et al., 2011): "I am always optimistic about my future", "I hardly ever expect things to go my way" and "If I try I can influence the quality of my living environment". Answers were scored on a 5- 
Baliatsas, C., Bolte, J., Yzermans, J., Kelfkens, G., Hooiveld, M., Lebret, E., Kamp, I. van. Actuah and perceived exposure to electromagnetic fields and non-specific physical symptoms: an epidemiological study based on self-reported data and electronic medical records. International7 Journal of Hygiene and Environmental Health: 2015

point Likert scale, with a higher sum score indicating less perceived control over a situation.

Avoidance (coping) behavior was assessed using a subscale of the Utrecht Coping List (Schreurs et al., 1993). Items were scored on a 4-point Likert scale; a higher score indicates increased avoidance behavior, representing the effort to avoid dealing with a stressful situation.

\section{Descriptive information and confounders}

Information was obtained on socio-demographic and lifestyle characteristics such as age, gender, education, foreign background, home ownership status, degree of urbanization, smoking habits and alcohol and/or substance abuse.

The EMF-related items of the Modern Health Worries (MHW) scale (Kaptein et al., 2005) was used to measure participants' levels of concern about potentially health effects due to mobile phones, base stations and high-voltage power lines.

\section{Statistical analyses}

Descriptive analyses were initially performed to obtain an overview of the distribution of socio-demographic characteristics, lifestyle indicators and EMF exposure in the sample. In the main analyses, the sum scores on symptom number and duration and sleep quality were treated as continuous variables, while the prevalence of GP-registered and single self-reported NSPS as binary. Considering the hierarchical structure of the data, preliminary multilevel analyses yielded no substantial clustering within general practices. Multiple linear and logistic regression models were carried out for the continuous and binary outcomes respectively. For each examined association, regression coefficients or odds ratios (OR) and 95\% confidence intervals (CIs) were computed. A $p$ value of $<0.05$ was considered statistically significant.

The association between health outcomes and actual and perceived exposure was examined, adjusted for a core set of a priori defined potential confounders, such as age, gender, education, foreign background, rented home, degree of urbanization, smoking habits and alcohol and/or substance abuse. Exposure-outcome associations were analyzed separately for each proxy of actual exposure.

Whether IEI-EMF affected the association between actual exposure and each of the primary outcomes was tested for by entering the interaction term (IEI-EMF $\times$ each actual exposure proxy; non-IEI-EMF participants comprised the reference group) (Aiken and West, 1991, Baron and Kenny, 1986 and Hayes, 2013) into the core models. The possible interaction of perceived exposure with IEI-EMF and psychological variables (worries, control, avoidance), was also examined by multiple regression analyses, testing each term separately.

Finally, perceived exposure and the psychological variables were entered in an expanded regression model to be tested as potential independent predictors of NSPS and sleep quality.

In case of significant associations between proxies of actual exposure and primary outcomes in the core exposure-outcome models, the tested interactions between perceived exposure and IEI-EMF and psychological variables were adjusted for these proxies, in order to verify the consistency of the findings. Respondents with $>5$ missing items on the self-reported NSPS list and $>2$ missing items on the sleep quality scale were excluded from the analyses. Symptoms from the medical records had no missing data. Analyses were carried out using the statistical software 
Baliatsas, C., Bolte, J., Yzermans, J., Kelfkens, G., Hooiveld, M., Lebret, E., Kamp, I. van. Actuah and perceived exposure to electromagnetic fields and non-specific physical symptoms: an epidemiological study based on self-reported data and electronic medical records. International7 Journal of Hygiene and Environmental Health: 2015

packages IBM SPSS Statistics (SPSS Inc., version 19, Chicago IL, USA) and R version 3.01 .

\section{Sensitivity analysis}

In addition to symptom scores, the prevalence (“in the past month") of single selfreported NSPS was assessed in relation to the examined actual exposure proxies, to enhance comparability with previous epidemiological studies that used similar outcome variables (Röösli et al., 2010a).

Selection was based on symptoms frequently investigated in the relevant epidemiological literature and pronounced among IEI-EMF sufferers (Baliatsas et al., 2014 and Röösli et al., 2010a): Headache, dizziness or feeling light-headed, fatigue/tiredness, memory/concentration problems, skin symptoms, heart palpitations and ear symptoms. Interaction analyses between IEI-EMF and actual exposure proxies were repeated for these symptoms.

In addition, the examined RF-EMF and ELF-MF exposure indicators were added in the same model to explore whether any alterations occurred regarding the exposureoutcome associations.

\section{RESULTS}

\section{Non-response and descriptive analysis}

Results of the non-response analysis, health characteristics and symptomatic profile of the participants (including those with IEI-EMF) have been described in detail elsewhere (Baliatsas et al., 2014). In summary, participants were somewhat younger, higher educated and reported better general health compared to non-respondents; no difference in gender distribution was observed.

There was a significant difference in the extent to which the two groups considered themselves as sensitive to mobile phone base stations and related communication systems ("quite agree"/"strongly agree" for respondents: $6.5 \%$ vs. non-respondents: $14 \%, p<0.001)$.

Table 1 gives an overview of basic sample characteristics.

\section{[TABLE 1]}

The most prevalent self-reported symptoms in the total sample were fatigue (54\%), neck or shoulder symptoms (39\%), headache (38\%), back pain (36\%), leg/hip/knee/foot symptoms (33\%) and muscular pain (31\%).

The predicted RF-EMF exposure levels are reported in Table 2 (all calculations were done in power density and back transformed to electric field). Inter-correlations (Spearman's rho) between different actual exposure proxies ranged between -0.06 and 0.4. The correlation between perceived exposure and the investigated proxies of RF-EMF exposure ranged between 0.1 and 0.2; the correlation with the ELF-MF sources ranged between -0.04 and 0.29 . Participants had a mean score of 11.3 (SD = 7.32) on the perceived exposure scale (score range: $0-30$ ).

\section{[TABLE 2]}

Among the respondents 202 (3.5\%) were considered as (hyper)sensitive to EMF, referred to as IEI-EMF, as defined above. Mean RF-EMF exposure levels were similar for both electrosensitive and non-sensitive individuals. 
Baliatsas, C., Bolte, J., Yzermans, J., Kelfkens, G., Hooiveld, M., Lebret, E., Kamp, I. van. Actuąh and perceived exposure to electromagnetic fields and non-specific physical symptoms: an epidemiological study based on self-reported data and electronic medical records. Internationalf Journal of Hygiene and Environmental Health: 2015

Participants with IEI-EMF less often reported use of an electric oven (61\% vs. 72\%, $p<0.001)$ and PC or laptop (74.5\% vs. $86.5 \%, p<0.001)$ but no other differences were observed in relation to other ELF-MF sources.

In addition, they reported higher levels of perceived exposure (mean score: 12.8 , $\mathrm{SD}=8.8$ vs. $11.3, \mathrm{SD}=7.2, p<0.05)$ and EMF-related worries $(7.0, \mathrm{SD}=3.6$, vs. $4.4, \mathrm{SD}=3.1, p<0.001)$.

\section{[FIGURE 2]}

No indication for multicollinearity was observed in the analyzed regression models as indicated by inter-correlations among the independent variables and the variance inflation factor (VIF) and tolerance value.

\section{ASSOCIATION BETWEEN NSPS AND MODELED RF-EMF}

Table 3 summarizes the results of the regression analyses. There was no significant association between modeled RF-EMF exposure and scores on self-reported NSPS, sleep quality or prevalence of NSPS in medical records.

\section{[TABLE 3]}

\section{ASSOCIATION BETWEEN NSPS AND SOURCES OF ELF-MF}

Consistent associations were observed between: (1) close distance to an electric charger ( $\leq 50 \mathrm{~cm}$ from head) during sleep and (2) use of an electric blanket and increased number and duration of self-reported NSPS and higher prevalence of GPregistered NSPS (Table 4).

\section{[TABLE 4]}

Furthermore, electric/ceramic hob use was significantly associated with lower sleep quality and induction hob use with GP-registered NSPS (Table 4). People using a pc or laptop tended to experience less sleep problems. No increased risk for NSPS was found in relation to close proximity to power lines.

\section{Association between NSPS and perceived EMF exposure}

Perceived exposure was consistently associated with the examined self-reported outcomes, even after adjustment for psychological variables; associations with GPregistered symptoms were mostly borderline significant (Table 3, Table 4 and Table $5)$.

\section{[TABLE 5]}

\section{Interaction between IEI-EMF and the association of actual and perceived exposure with NSPS}

The number of regression analyses performed for the different exposures, endpoints and interaction terms precludes the presentation of the data. Therefore, only the few significant interaction terms are mentioned: Analyses showed a trend for increased score on number of symptoms in relation to downlink exposure for participants in the IEI-EMF group (regression coefficient: $0.34,95 \% \mathrm{CI}=0.04-0.64, p<0.05$ ). This was also the case for the interaction term between sleeping in close distance to an electric alarm clock and sleep problems (regression coefficient: $1.21,95 \%$ CI $=0.13$ 
Baliatsas, C., Bolte, J., Yzermans, J., Kelfkens, G., Hooiveld, M., Lebret, E., Kamp, I. van. Actuah and perceived exposure to electromagnetic fields and non-specific physical symptoms: an epidemiological study based on self-reported data and electronic medical records. International7 Journal of Hygiene and Environmental Health: 2015

2.3, $p<0.05)$. No significant interaction was observed between IEI-EMF and perceived exposure ( $p$ values ranging from 0.1 to 0.4 ; results not shown).

\section{NSPS and perceived control and coping}

Analyses showed no significant moderation of perceived control and avoidance on the association between perceived exposure and outcomes. The association between perceived exposure and self-reported outcomes remained consistent after adjustment for psychological factors. Lower perceived control was a consistent predictor of the examined outcomes (Table 5).

\section{Sensitivity analysis}

Analyses yielded no association between the investigated RF frequency bands and prevalence of single self-reported NSPS, except for a negative association between uplink exposure and prevalence of headache and dizziness (Appendix, Table 6). Regarding sources of ELF-MF, sleeping close to a charger was associated with fatigue, while the use of an electric blanket was associated with dizziness, fatigue, palpitations and ear symptoms. There was also a negative association between using a pc or laptop and fatigue (Appendix, Table 7).

When all exposure indicators were included in the same regression model (except for “GSM900” and "GSM1800”, which were represented in "downlink”), results on actual and perceived exposure remained consistent (data not shown).

Furthermore, it was found that the association between GSM900 exposure and ear symptoms differed significantly between individuals with IEI-EMF and the remaining sample $(\mathrm{OR}=1.87,95 \% \mathrm{CI}=1.01-3.46, p<0.05)$. A significant higher risk for memory or concentration problems in relation to the use of electric blanket was also observed among participants with IEI-EMF (OR $=3.2$, 95\% CI $=1.02$ $10.1, p<0.05)$.

\section{DISCUSSION}

This is the first epidemiological study into the association between actual and perceived EMF exposure and NSPS and sleep quality combining self-reported and medical record data. A number of theory-based psychological variables were included in the analyses as potential outcome predictors or effect modifiers of the association between perceived exposure and outcomes. The role of perceived exposure in the association between psychological variables and symptoms was also explored. The potential effect modification of IEI-EMF on the (actual and perceived) exposure-outcome association was investigated as well. In the absence of a known biological mechanism related to residential-level EMF and NSPS, a large number of exposure sources and health outcomes were examined as recommended in the literature (Frei et al., 2012 and Mohler et al., 2012). The documented levels of RFEMF exposure were on average far below the current reference levels (ICNIRP, 1998). For this reason our conclusions are limited to low exposure levels.

\section{Exposure-outcome associations}

Results, including sensitivity analyses, did not indicate an association between modeled RF-EMF exposure and number and duration of self-reported NSPS and prevalence of GP-registered NSPS. Furthermore, no significant association was observed between RF-EMF bands and self-reported sleep quality. As highlighted by Mohler et al. (2012) if such an association existed, a consistent pattern toward a harmful effect would be expected, even if it was statistically non-significant; this was 
Baliatsas, C., Bolte, J., Yzermans, J., Kelfkens, G., Hooiveld, M., Lebret, E., Kamp, I. van. Actuah and perceived exposure to electromagnetic fields and non-specific physical symptoms: an epidemiological study based on self-reported data and electronic medical records. Internationaly Journal of Hygiene and Environmental Health: 2015

not the case. These findings confirm those from recent epidemiological studies in Europe on RF-EMF and NSPS and sleep quality (Berg-Beckhoff et al., 2009, Frei et al., 2012, Heinrich et al., 2011, Mohler et al., 2010, Mohler et al., 2012 and Thomas et al., 2008).

Regarding the examined ELF-MF sources, there is not much evidence in the literature to compare the current results with, except for the lack of an association between NSPS and geo-coded distance to power lines (Baliatsas et al., 2011). Analyses yielded a consistent association between NSPS and use of an electric blanket. A possible explanation is reverse causality, given that people who experience physical symptoms might use such an appliance more often.

Nevertheless, an electric blanket is considered to be a source of high exposure (Florig and Hoburg, 1990). Associations were also observed between NSPS and distance to an electric charger ( $\leq 50 \mathrm{~cm}$ from the head) during sleep and use of an induction hob and GP-registered NSPS. Further research on the association with these sources is required to replicate these observations. Sporadic associations, some of them negative, were found for other sources such as induction hob, electric/ceramic hob and pc or laptop. Considering the large number of regression models carried out, a few statistically significant associations are expected by chance; negative associations have been previously observed in the literature, independently of study design (Augner et al., 2009, Heinrich et al., 2011, NietoHernandez et al., 2011 and Thomas et al., 2008).

Perceived exposure was a consistent predictor of the self-reported health indicators across the models, which is in agreement with the limited epidemiological evidence in the peer-reviewed literature (Baliatsas et al., 2011 and Baliatsas et al., 2012b). The correlation between perceived and actual exposure (based on the different surrogates) was either low or negligible, which strengthens the notion that perceived exposure should not be considered as a proxy of actual exposure levels (Baliatsas et al., 2012b, Frei et al., 2010 and Vrijheid et al., 2009) but rather as an independent predictor of NSPS, as experimental evidence suggests (Röösli, 2008, Röösli et al., 2010a and Rubin et al., 2010). This low correlation also shows that most of the respondents were not aware of their (most) relevant sources of exposure, which in turn indicates that the risk for information bias was rather low in this study.

\section{IEI-EMF}

The actual exposure status of individuals with IEI-EMF in our sample did not differ substantially compared to the rest of the participants. Overall, we found no convincing evidence that individuals who reported to be sensitive to EMF experienced more severe symptoms or lower sleep quality in relation to actual or perceived EMF than the rest of the population, which is in line with recent studies (Frei et al., 2012, Mohler et al., 2012 and Röösli et al., 2010b). Nevertheless, we observed a trend for increased score on number of symptoms in relation to downlink exposure and also a significant interaction between sleeping in close distance to an electric alarm clock and sleep problems.

Sensitivity analyses also showed a significant interaction of IEI-EMF with GSM900 and use of an electric blanket, in relation to ear symptoms and memory/concentration problems respectively. The existence of interactions have been mentioned in previous studies (Frei et al., 2012) but no consistent pattern can be discerned. These findings should be interpreted with caution, since false-positives are likely due to the 
Baliatsas, C., Bolte, J., Yzermans, J., Kelfkens, G., Hooiveld, M., Lebret, E., Kamp, I. van. Actuah and perceived exposure to electromagnetic fields and non-specific physical symptoms: an epidemiological study based on self-reported data and electronic medical records. Internationalf Journal of Hygiene and Environmental Health: 2015

large number of interactions tested, in relation to numerous outcomes (Grobbee and Hoes, 2009).

Epidemiological research on potentially susceptible groups of sufficient sample sizes is still limited and further investigation would help us get a better understanding regarding possible effects of environmental EMF exposure (Bogers et al., 2013).

\section{Implications for psychological mechanisms}

Given the limited evidence in the literature for a mechanism for EMF-related NSPS and since our cross-sectional study design cannot establish temporal precedence, the analyses of effect modification in the current study was exploratory; a first attempt to test theoretically relevant determinants of NSPS in a large population sample, taking actual exposure into account. Our results showed that, in addition to perceived exposure, perceived control and avoidance coping were associated with the examined outcomes, with the former being the strongest and most consistent predictor. Perhaps in the case of EMF symptoms, increased avoidance may also have an alleviating effect on symptoms (Hagström et al., 2013) which could potentially mask a more consistent positive association with NSPS.

Although a combination of multiple factors can play a role in the experience and maintenance of NSPS (Engel and Katon, 1999 and Walker et al., 1998), the present findings highlight the importance of cognitions and behavior within the EMF context: Considering an environmental source as potentially hazardous could increase symptom report or severity when perceiving exposure (Szemerszky et al., 2010 and Winters et al., 2003). Since environmental stressors are often outside individual control (Campbell, 1984), lower perceived control over the stressor could be an important factor toward increase in preoccupation with and amplification of bodily reactions (Kroenke and Swindle, 2000). This in turn could increase the likelihood of avoidance coping behavior (Nordin et al., 2010).

The role of perceived exposure in a transactional process needs to be further clarified, together with additional theoretically relevant variables such as environmental worries, negative affectivity and somatosensory amplification (Witthöft and Rubin, 2013). Longitudinal data could allow for the investigation of aspects that are not obtainable in cross-sectional design, such as stability across time and temporal precedence (MacKinnon et al., 2007).

\section{Study strengths}

To our knowledge, the present study is the largest performed in this field. The inclusion of various exposure surrogates and the large number of examined outcomes allowed the assessment of consistency and biological tenability of the findings, given that no bioelectromagnetic mechanism has been established.

We used a prediction model to characterize RF-EMF levels, based on a number of exposure-related everyday life activities and exposure to mobile phone base stations (Bolte and Eikelboom, 2012 and Neitzke et al., 2007).

While the RF-EMF exposure models leave room for improvement, the explained variance of the prediction model was compared reasonably well with the model developed in Switzerland (Frei et al., 2009 and Frei et al., 2010). The higher proportion of explained variance in the Swiss study is in part due to the use of the three-dimensional propagation model used, compared to the ECOLOG model. The mean values of exposure levels and per band ranges coincided with those reported in other European surveys (Frei et al., 2010, Viel et al., 2009 and Viel et al., 2011). The 
Baliatsas, C., Bolte, J., Yzermans, J., Kelfkens, G., Hooiveld, M., Lebret, E., Kamp, I. van. Actuah and perceived exposure to electromagnetic fields and non-specific physical symptoms: an epidemiological study based on self-reported data and electronic medical records. Internationaly Journal of Hygiene and Environmental Health: 2015

use of exposure prediction models instead of spot or exposimeter measurements is a time- and cost-effective approach for large epidemiological studies and represent daily life exposure conditions (Bolte et al., 2011 and Frei et al., 2010).

In addition, this is amongst the first research efforts to analyze NSPS in relation to sources of ELF-MF. In the absence of a predictive model of personal exposure to ELF-MF, the assessment of exposure to fields from electrical appliances was solely build on geographic and questionnaire information; we used a binary/“use vs. no use" assessment in order to reduce recall bias, which can be introduced by the use of self-reported questionnaires (Mezei et al., 2001).

We tried to minimize sources of bias related to study design as much as possible. The questions regarding indoor electrical appliances and perceived EMF exposure were asked after the questions about health outcomes. Furthermore, the questionnaire items on activity patterns did not explicitly relate EMF to the activities. Self-reported outcomes were previously assessed across environmentally sensitive groups (Baliatsas et al., 2014) and we used medical record data from a registry system with established reliability (Lamberts et al., 2005). In the absence of an internationally recognized case definition for IEI-EMF, inclusion criteria were based on the dominant definitions in the peer-reviewed experimental and observational literature (Baliatsas et al., 2012a). Finally, the response rate of the survey is considered satisfactory and comparable to other studies on residential EMF exposure and NSPS (Baliatsas et al., 2012b).

\section{Study limitations}

Besides the cross-sectional nature of the study, some limitations should be acknowledged. Regarding the propagation (ECOLOG) model which was used to estimate residential exposure to mobile phone base stations (Neitzke et al., 2007), only information on the maximum antenna power was available. The antenna dataset did not contain information regarding the tilt of the individual antennas (fixed tilt was used for all antennas). Shielding by vegetation or buildings is not included in the ECOLOG estimation, nor does it account for the further propagation of the signal indoors; it stops after penetration of the signal through the wall or window of the bedroom. Such limitations in the input data reduce the accuracy of exposure prediction (Beekhuizen et al., 2014a). A geospatial model based on detailed threedimensional data on the neighborhood would have higher accuracy. At the onset of this study, however, such data was not yet available, but much progress has been made recently (Beekhuizen et al., 2014b). Finally, an aspect that could influence specificity of the ECOLOG model was the incomplete questions (23\%) in the main epidemiological survey.

In terms of the AEM based models, exposure-related activities might, apart from exposure, also reflect lifestyle characteristics, that in themselves might be associated with health endpoints. Moreover, the explained variance of the prediction model for WiFi exposure was too low to be considered and assessment of mobile phone use was not possible due to the lack of objective operator data. Finally, the explained variance of the prediction models for RF-EMF, was relatively low. This indicates some exposure error and misclassification that may affect the study's statistical power and regression coefficients. Given the size of the study, effects on statistical power may be less important here. Given that a prediction model was not available at the time the present project was running, exposure to ELF-MF was based on geocoded distance and indoor electric devices on self-reports, which are known to be 
Baliatsas, C., Bolte, J., Yzermans, J., Kelfkens, G., Hooiveld, M., Lebret, E., Kamp, I. van. Actuah and perceived exposure to electromagnetic fields and non-specific physical symptoms: an epidemiological study based on self-reported data and electronic medical records. International Journal of Hygiene and Environmental Health: 2015

prone to exposure misclassification (Bonnet-Belfais et al., 2013 and Leitgeb et al., 2007).

Another possible limitation is related to the ICPC codes we used to identify GPregistered NSPS. It cannot be ruled out that not all symptoms presented by the patients were registered by the GP or the GP used a code that was not considered as corresponding to the self-reported NSPS. This could lead to an underestimation of the prevalence of registered NSPS in the study sample. In addition, some of the participants might have been diagnosed with a medical condition before or after the time interval we used to define an episode of care as "non-specific". Finally, the respondents were somewhat healthier and reported to be less sensitive to base stations and wireless communication systems than the non-respondents.

This may have led to an underestimation of the examined health outcomes. When only sensitive individuals would experience health problems, an underrepresentation of sensitive individuals would reduce the power to detect such an exposure-outcome associations in a sensitive subgroup.

\section{CONCLUSIONS}

In conclusion, this study provides no evidence for an association between everyday life RF-EMF exposure and NSPS and sleep quality in the population. This may, in part, be a result of exposure error and misclassification. Better exposure characterization, in particular with respect to ELF-MF is needed to draw more solid conclusions. Perceived exposure, perceived control and avoidance coping were associated with the examined health outcomes. There was some indication, but no consistent pattern, for a potential moderating role of IEI-EMF on the association between actual exposure and symptoms. Longitudinal approaches within a multidisciplinary framework can further elucidate the underlying mechanisms in this research field.

Funding source: The current study is part of the Dutch project EMPHASIS "Nonspecific physical symptoms in relation to actual and perceived exposure to EMF and the underlying mechanisms", funded by The Netherlands Organization for Health Research and Development (ZonMw) (project number: 85100002). The study sponsor had no involvement in study design, collection, analysis, writing and interpretation of the data and in the decision to submit the study for publication. Conflict of interest: None declared.

Acknowledgements: We gratefully acknowledge the cooperation of respondents and GPs. We would like to thank Oscar Breugelmans, Erica Maurits and Dr. Lando Koppes for their feedback on the paper. In addition, we would like to thank Caroline Ameling (statistical advice), Petra ten Veen and Elsbeth Leeuw-Stravers (data management of EMRs).

\section{APPENDiX.}

\section{[TABLE 6 AND TABLE 7]}

\section{REFERENCES}

L.S. Aiken, S.G. West Multiple Regression: Testing and Interpreting Interactions Newbury Park, Sage (1991) 
Baliatsas, C., Bolte, J., Yzermans, J., Kelfkens, G., Hooiveld, M., Lebret, E., Kamp, I. van. Actuah and perceived exposure to electromagnetic fields and non-specific physical symptoms: an epidemiological study based on self-reported data and electronic medical records. International7 Journal of Hygiene and Environmental Health: 2015

C. Augner, M. Florian, G. Pauser, G. Oberfeld, G.W. Hacker GSM base stations: short-term effects on well-being Bioelectromagnetics, 30 (2009), pp. 73-80

C. Augner, T. Gnambs, R. Winker, A. Barth Acute effects of electromagnetic fields emitted by GSM mobile phones on subjective well-being and physiological reactions: a metaanalysis Sci. Total Environ., 424 (2012), pp. 11-15

R. Baan, Y. Grosse, B. Lauby-Secretan, F. El Ghissassi, V. Bouvard, L. Benbrahim-Tallaa, et al. Carcinogenicity of radiofrequency electromagnetic fields Lancet Oncol., 12 (2011), pp. 624-626

C. Baliatsas, I. Van Kamp, G. Kelfkens, M. Schipper, J. Bolte, J. Yzermans, et al.Nonspecific physical symptoms in relation to actual and perceived proximity to mobile phone base stations and powerlines BMC Public Health, 11 (2011), p. 421

C. Baliatsas, I. van Kamp, E. Lebret, G.J. Rubin Idiopathic environmental intolerance attributed to electromagnetic fields (IEI-EMF): a systematic review of identifying criteria

BMC Public Health, 12 (2012), p. 643

C. Baliatsas, I. van Kamp, J. Bolte, M. Schipper, J. Yzermans, E. Lebret Non-specific physical symptoms and electromagnetic field exposure in the general population: can we get more specific? A systematic review Environ. Int., 41 (2012), pp. 15-28

C. Baliatsas, I. Van Kamp, M. Hooiveld, J. Yzermans, E. Lebret Comparing non-specific physical symptoms in environmentally sensitive patients: prevalence, duration, functional status and illness behavior J. Psychosom. Res., 76 (2014), pp. 405-413

C. Baliatsas, G.J. Rubin Electromagnetic fields, symptoms and idiopathic environmental intolerance M. Röösli (Ed.), Epidemiology of Electromagnetic Fields, CRC Press (2014), pp. 261-274

R.M. Baron, D.A. Kenny The moderator-mediator variable distinction in social psychological research: conceptual, strategic, and statistical considerations J. Pers. Soc. Psychol., 51 (1986), pp. 1173-1182

J. Beekhuizen, G.B.M. Heuvelink, A. Huss, A. Bürgi, H. Kromhout, R. Vermeulen Impact of input data uncertainty on environmental exposure assessment models: a case study for electromagnetic field modelling from mobile phone base stations Environ. Res., 135 (2014), pp. 148-155

J. Beekhuizen, R. Vermeulen, M. van Eijsden, R. van Strien, A. Bürgi, E. Loomans, et al. Modelling indoor electromagnetic fields (EMF) from mobile phone base stations for epidemiological studies Environ. Int., 67 (2014), pp. 22-26

G. Berg-Beckhoff, M. Blettner, B. Kowall, J. Breckenkamp, B. Schlehofer, S. Schmiedel, et al. Mobile phone base stations and adverse health effects: phase 2 of a cross-sectional study with measured radio frequency electromagnetic fields Occup. Environ. Med., 66 (2009), pp. 124-130

R.P. Bogers, J.F.B. Bolte, J.H. Houtveen, E. Lebret, R. van Strien, M. Schipper, et al.Design of an ecological momentary assessment study of exposure to radiofrequency lectromagnetic fields and non-specific physical symptoms BMJ Open, 3 (2013), p. e002933 10.1136/bmjopen-2013-002933.

J. Bolte, M. Pruppers, J. Kamer, G. van der Zande, M. Schipper, S.R. Fleurke, et al.The Dutch Exposimeter study: developing an activity exposure matrix Epidemiology, 19 (2008), pp. s78-s79

J. Bolte, G. Van der Zande, J. Kamer Calibration and uncertainties in personal exposure measurements of radiofrequency electromagnetic fields Bioelectromagnetics, 32 (2011), pp. 652-663

J.F.B. Bolte, T. Eikelboom Personal radiofrequency electromagnetic field measurements in the Netherlands: exposure level and variability for everyday activities, times of day and types of area Environ. Int., 48 (2012), pp. 133-142

J. Bolte, I. van Kamp, M. Pruppers, J. Kamer, G. van der Zande, M. Schipper, et al. The Dutch personal EMF exposure study: measurements during everyday activities combined with GPS to build an Activity Exposure Matrix (EMF-AEM) Proceedings: BioEM2013, The Bioelectromagnetics Society, Thessaloniki (2013)

M. Bonnet-Belfais, J. Lambrozo, A. Aurengo Comment on 'Childhood leukemia close to highvoltage power lines - the Geocap study, 2002-2007' - is proximity an appropriate MF exposure surrogate? Br. J. Cancer, 109 (2013), pp. 1382-1383

J.M. Campbell Ambient stressors Environ. Behav., 15 (1984), pp. 355-380 
Baliatsas, C., Bolte, J., Yzermans, J., Kelfkens, G., Hooiveld, M., Lebret, E., Kamp, I. van. Actuah and perceived exposure to electromagnetic fields and non-specific physical symptoms: an epidemiological study based on self-reported data and electronic medical records. International7 Journal of Hygiene and Environmental Health: 2015

Q. Chen, L. Lang, W. Wu, G. Xu, X. Zhang, T. Li, et al. A meta-analysis on the relationship 545 between exposure to ELF-EMFs and the risk of female breast cancer PLoS ONE, 8 (2013), p. e69272

C.C. Engel, W.J. Katon Population and need-based prevention of unexplained symptoms in the community Institute of Medicine, Strategies to Protect the Health of Deployed U.S. Forces: Medical Surveillance, Record Keeping, and Risk ReductionNational Academy Press, Washington, DC (1999), pp. 173-212

H.K. Florig, J.F. Hoburg Power-frequency magnetic fields from electric blankets Health Phys., 58 (1990), pp. 493-502

P. Frei, E. Mohler, A. Bürgi, J. Fröhlich, G. Neubauer, C. Braun-Fahrländer, et al. A prediction model for personal radio frequency electromagnetic field exposure Sci. Total Environ., 408 (2009), pp. 102-108

P. Frei, E. Mohler, A. Bürgi, J. Fröhlich, G. Neubauer, C. Braun-Fahrländer, et al. Classification of personal exposure to radio frequency electromagnetic fields (RF-EMF) for epidemiological research: evaluation of different exposure assessment methods Environ. Int., 36 (2010), pp. 714-720

P. Frei, E. Mohler, C. Braun-Fahrländer, J. Fröhlich, G. Neubauer, M. Röösli Cohort study on the effects of everyday life radio frequency electromagnetic field exposure on non-specific symptoms and tinnitus Environ. Int., 38 (2012), pp. 29-36

U. Frick, J. Rehm, P. Eichhammer Risk perception, somatization, and self report of complaints related to electromagnetic fields-a randomized survey study Int. J. Hyg. Environ. Health, 205 (2002), p. 353

S.J. Genuis, C.T. Lipp Electromagnetic hypersensitivity: fact or fiction? Sci. Total Environ., 414 (2011), pp. 103-112

D.E. Grobbee, A.W. Hoes Clinical Epidemiology - Principles, Methods and Applications for Clinical Research Jones and Bartlett Publishers, London (2009)

M. Hagström, J. Auranen, R. Ekmanm Electromagnetic hypersensitive Finns: symptoms, perceived sources and treatments, a questionnaire study Pathophysiology, 20 (2013), pp. 117-122

A.F. Hayes Introduction to Mediation, Moderation, and Conditional Process Analysis: A Regression based Approach The Guilford Press, New York, NY (2013)

S. Heinrich, S. Thomas, G. Praml, R. von Kries, K. Radon The impact of exposure to radio frequency electromagnetic fields on chronic wellbeing in young people - a cross sectional study based on personal dosimetry Environ. Int., 37 (2011), pp. 26-30

L. Hillert, N. Leitgeb, J. Meara Working group report K.H. Mild, M. Repacholi, E. Van Deventer, P. Ravazzani (Eds.), Electromagnetic Hypersensitivity. Proceedings: International Workshop on EMF Hypersensitivity, WHO, Prague (2006), pp. 15-26

H.P. Hutter, L. Ehrenhöfer, E. Freuis, P. Hartl, M. Kundi Poor-to-moderate agreement between self and proxy interviews of mobile phone use Bioelectromagnetics, 33 (2012), pp. 561-567

International Commission on Non-Ionizing Radiation Protection Guidelines for limiting exposure to time-varying electric, magnetic, and electromagnetic fields (up to $300 \mathrm{GHz}$ ) Health Phys., 74 (1998), pp. 494-522

I. Inyang, G. Benke, R. McKenzie, M. Abramson Comparison of measuring instruments for radiofrequency radiation from mobile telephones in epidemiological studies: implications for exposure assessment J. Expo. Sci. Environ. Epidemiol., 18 (2008), pp. 134-141

A. Johansson, S. Nordin, M. Heiden, M. Sandström Symptoms, personality traits, and stress in people with mobile phone-related symptoms and electromagnetic hypersensitivity $\mathrm{J}$. Psychosom. Res., 68 (2010), pp. 37-45

A.A. Kaptein, D.I. Helder, W.C. Kleijn, W. Rief, R. Moss-Morris, K.J. Petrie Modern health worries in medical students J. Psychosom. Res., 58 (2005), pp. 453-457

G. Kelfkens, C. Baliatsas, J. Bolte, I. Van Kamp ECOLOG based estimation of exposure to mobile phone base stations in the Netherlands Proceedings: 7th International Workshop on Biological Effects of EMF, 978-99957-0-361-5, Electromagnetic Research Group (EMRG), Valletta (2012)

R.A. Kleinerman, M.S. Linet, E.E. Hatch, R.E. Tarone, P.M. Black, R.G. Selker, et al.Selfreported electrical appliance use and risk of adult brain tumors Am. J. Epidemiol., 161 (2005), pp. 136-146 
Baliatsas, C., Bolte, J., Yzermans, J., Kelfkens, G., Hooiveld, M., Lebret, E., Kamp, I. van. Actuał and perceived exposure to electromagnetic fields and non-specific physical symptoms: an epidemiological study based on self-reported data and electronic medical records. International Journal of Hygiene and Environmental Health: 2015

F. Koteles, R. Szemerszky, A. Freyler, G. Bardos Somatosensory amplification as a possible source of subjective symptoms behind modern health worries Scand. J. Psychol., 52 (2011), pp. 174-178

B. Kowall, J. Breckenkamp, M. Blettner, B. Schlehofer, J. Schuz, G. Berg-Beckhoff Determinants and stability over time of perception of health risks related to mobile phone base stations Int. J. Public Health, 57 (2012), pp. 735-743

K. Kroenke, R. Swindle Cognitive-behavioral therapy for somatization and symptom syndromes: a critical review of controlled clinical trials Psychother. Psychosom., 69 (2000), pp. 205-215

H. Lamberts, M. Wood International Classification of Primary Care Oxford University Press, Oxford (1987)

H. Lamberts, S.K. Oskam, I.M. Okkes The clinical relationship between symptoms and the final diagnosis in general practice, determined by means of posterior probabilities calculated on the basis of the Transition Project Ned. Tijdschr. Geneeskd., 149 (2005), pp. 2566-2572 (in Dutch)

M. Landgrebe, U. Frick, S. Hauser, B. Langguth, R. Rosner, G. Hajak, P. Eichhammer Cognitive and neurobiological alterations in electromagnetic hypersensitive patients: results of a case-control study Psychol. Med., 38 (2008), pp. 1781-1791

R.S. Lazarus, S. Folkman Stress, Appraisal and Coping Springer-Verlag, New York (1984) N. Leitgeb, R. Cech, J. Schröttner, P. Lehofer, U. Schmidpeter, M. Rampetsreiter Magnetic emissions of electric appliances Int. J. Hyg. Environ. Health, 211 (2007), pp. 69-73

N. Leitgeb Macht Mobilfunk Kinder krank Monatsschr. Kinderheilkd., 160 (2012), pp. 461467 (in German)

D.P. MacKinnon, A.J. Fairchild, M.S. Fritz Mediation analysis Annu. Rev. Psychol., 58 (2007), pp. 593-614

S. Mann Assessing personal exposures to environmental radiofrequency electromagnetic fields C.R. Phys., 11 (2010), pp. 541-555

G. Mezei, L.I. Kheifets, L.M. Nelson, K.M. Mills, R. Iriye, J.L. Kelsey Household appliance use and residential exposure to $60-\mathrm{Hz}$ magnetic fields J. Expo. Anal. Environ. Epidemiol., 11 (2001), pp. 41-49

E. Mohler, P. Frei, C.B. Fahrländer, J. Fröhlich, G. Neubauer, M. Röösli Effects of everyday radiofrequency electromagnetic-field exposure on sleep quality: a cross-sectional study

Radiat. Res., 174 (2010), pp. 347-356

E. Mohler, P. Frei, J. Fröhlich, C. Braun-Fahrländer, M. Röösli Exposure to radiofrequency electromagnetic fields and sleep quality: a prospective cohort study PLoS One, 7 (2012) e37455

H.P. Neitzke, J. Osterhoff, K. Peklo, H. Voigt, T. Wohlatz Bestimmung der Exposition von Personengruppen, die im Rahmen des Projektes "Querschnittstudie zur Erfassung und Bewertung möglicher gesundheitlicher Beeinträchtigungen durch die Felder von Mobilfunkbasisstationen" untersucht werden Schlussbericht, Ecolog- Institut, Hannover (2005) (in German)

H.P. Neitzke, J. Osterhoff, K. Peklo, H. Voigt Determination of exposure due to mobile phone base stations in an epidemiological study Radiat. Prot. Dosim., 124 (2007), pp. 35-39

R. Nieto-Hernandez, J. Williams, A.J. Cleare, S. Landau, S. Wessely, G.J. Rubin Can exposure to a terrestrial trunked radio (TETRA)-like signal cause symptoms? A randomized double-blind provocation study Occup. Environ. Med., 68 (2011), pp. 339-344

M. Nordin, L. Andersson, S. Nordin Coping strategies, social support and responsibility in chemical Intolerance J. Clin. Nurs., 19 (2010), pp. 2162-2173

W. Rief, E. Broadbent Explaining medically unexplained symptoms-models and mechanisms Clin. Psychol. Rev., 27 (2007), pp. 821-841

M. Röösli Radiofrequency electromagnetic field exposure and non-specific symptoms of ill health: a systematic review Environ. Res., 107 (2008), pp. 277-287

M. Röösli, P. Frei, E. Mohler, K. Hug Systematic review on the health effects of exposure to radiofrequency electromagnetic fields from mobile phone base stations Bull. World Health Organ., 88 (2010), pp. 887-896

M. Röösli, E. Mohler, P. Frei Sense and sensibility in the context of radiofrequency electromagnetic field exposure C.R. Phys., 11 (2010), pp. 576-584 
Baliatsas, C., Bolte, J., Yzermans, J., Kelfkens, G., Hooiveld, M., Lebret, E., Kamp, I. van. Actuah and perceived exposure to electromagnetic fields and non-specific physical symptoms: an epidemiological study based on self-reported data and electronic medical records. International7 Journal of Hygiene and Environmental Health: 2015

G.J. Rubin, A.J. Cleare, S. Wessely Psychological factors associated with self-reported sensitivity to mobile phones J. Psychosom. Res., 64 (2008), pp. 1-9

G.J. Rubin, R. Nieto-Hernandez, S. Wessely Idiopathic environmental intolerance attributed to electromagnetic fields (formerly 'electromagnetic hypersensitivity'): an updated systematic review of provocation studies Bioelectromagnetics, 31 (2010), pp. 1-11

G.J. Rubin, L. Hillert, R. Nieto-Hernandez, E. Van Rongen, G. Oftedal Do people with idiopathic environmental intolerance attributed to electromagnetic fields display physiological effects when exposed to electromagnetic fields? A systematic review of provocation studies Bioelectromagnetics, 32 (2011), pp. 593-609

P.J.G. Schreurs, G. Van de Willige, J.F. Brosschot, B. Tellegen, G.M.H. Graus De Utrechtse Coping Lijst: UCL. Omgaan met problemen en gebeurtenissen [The Utrecht Coping List, Coping with Problems and Events] Swets \& Zeitlinger, Lisse (1993)

M. Shum, M.A. Kelsh, A.R. Sheppard, K. Zhao An evaluation of self-reported mobile phone use compared to billing records among a group of engineers and scientists Bioelectromagnetics, 32 (2011), pp. 37-48

R. Szemerszky, F. Koteles, R. Lihi, G. Bardos Polluted places or polluted minds? An experimental sham-exposure study on background psychological factors of symptom formation in 'idiophatic environmental intolerance' attributed to electromagnetic fields Int. J. Hyg. Environ. Health, 213 (2010), pp. 387-394

S. Thomas, A. Kühnlein, S. Heinrich, G. Praml, D. Nowak, R. von Kries Personal exposure to mobile phone frequencies and well-being in adults - a cross-sectional study based on dosimetry Bioelectromagnetics, 29 (2008), pp. 463-470

A. Tuengler, L. von Klitzing Hypothesis on how to measure electromagnetic hypersensitivity Electromag. Biol. Med., 32 (2013), pp. 281-290

B. van den Berg, L. Grievink, R.K. Stellato, C.J. Yzermans, E. Lebret Symptoms and related functioning in a traumatized community Arch. Intern. Med., 165 (2005), pp. 2402-2407

B. van den Berg Physical symptoms that are frequently unexplained among survivors of the Enschede fireworks disaster (Doctoral dissertation) Utrecht University (2007)

I. van Kamp Coping with noise and its health consequences (Doctoral dissertation) University of Groningen (1990)

J.F. Viel, E. Cardis, M. Moissonnier, R. de Seze, M. Hours Radiofrequency exposure in the French general population: band, time, location and activity variability Environ. Int., 35 (2009), pp. 1150-1154

J.F. Viel, M. Tiv, M. Moissonnier, E. Cardis, M. Hours Variability of radiofrequency exposure across days of the week: a population-based study Environ. Res., 111 (2011), pp. 510-513

P. Visser, W.F. Hofman, A. Kumar, R. Cluydts, I.P.F. de Diana, P. Marchant, et al. Sleep and Mood: measuring the sleep quality

R.G. Priest, A. Pletscher, J. Ward (Eds.), Sleep Research, Proc. of the North Eur. Symp. on Sleep Research, MTP Press Limited, Basel, Lancaster (1978), pp. 135-145

M. Vrijheid, B.K. Armstrong, D. Bédard, J. Brown, I. Deltour, I. lavarone, et al. Recall bias in the assessment of exposure to mobile phones J. Expo. Sci. Environ. Epidemiol., 19 (2009), pp. 369-381

E.A. Walker, J. Unutzer, W.J. Katon Understanding and caring for the distressed patient with multiple medically unexplained symptoms J. Am. Board Fam. Pract., 11 (1998), pp. 347356

W. Winters, S. Devriese, I.V. Diest, B. Nemery, H. Veulemans, P. Eelen, et al. Media warnings about environmental pollution facilitate the acquisition of symptoms in response to chemical substances Psychosom. Med., 65 (2003), pp. 332-338

M. Witthöft, G.J. Rubin Are media warnings about the adverse health effects of modern life self-fulfilling? An experimental study on idiopathic environmental intolerance attributed to electromagnetic fields (IEI-EMF) J. Psychosom. Res., 74 (2013), pp. 206-212

WONCA Classification Committee An international glossary for general/family practice Fam. Pract., 12 (1995), pp. 341-369

J. Yzermans, C. Baliatsas, I. Van Kamp Symptoms and perceptions scale (SaP): an exploratory psychometric analysis Psychol. Health, 27 (2012), pp. s1-s354

L. Zhao, X. Liu, C. Wang, K. Yan, X. Lin, S. Li, et al. Magnetic fields exposure and childhood leukemia risk: a meta-analysis based on 11,699 cases and 13,194 controls Leuk. Res., 38 (2014), pp. 269-274 
Baliatsas, C., Bolte, J., Yzermans, J., Kelfkens, G., Hooiveld, M., Lebret, E., Kamp, I. van. Actuałh and perceived exposure to electromagnetic fields and non-specific physical symptoms: an epidemiological study based on self-reported data and electronic medical records. Internationaly Journal of Hygiene and Environmental Health: 2015

T. Zheng, T.R. Holford, S.T. Mayne, P. Hansen Owens, B. Zhang, P. Boyle, et al. Exposure to electromagnetic fields from use of electric blankets and other in-home electrical appliances and breast cancer risk Am. J. Epidemiol., 151 (2000), pp. 1103-1111

\section{TABLES AND FIGURES}

Fig. 1. Schematic illustration of the study design and sampling process.

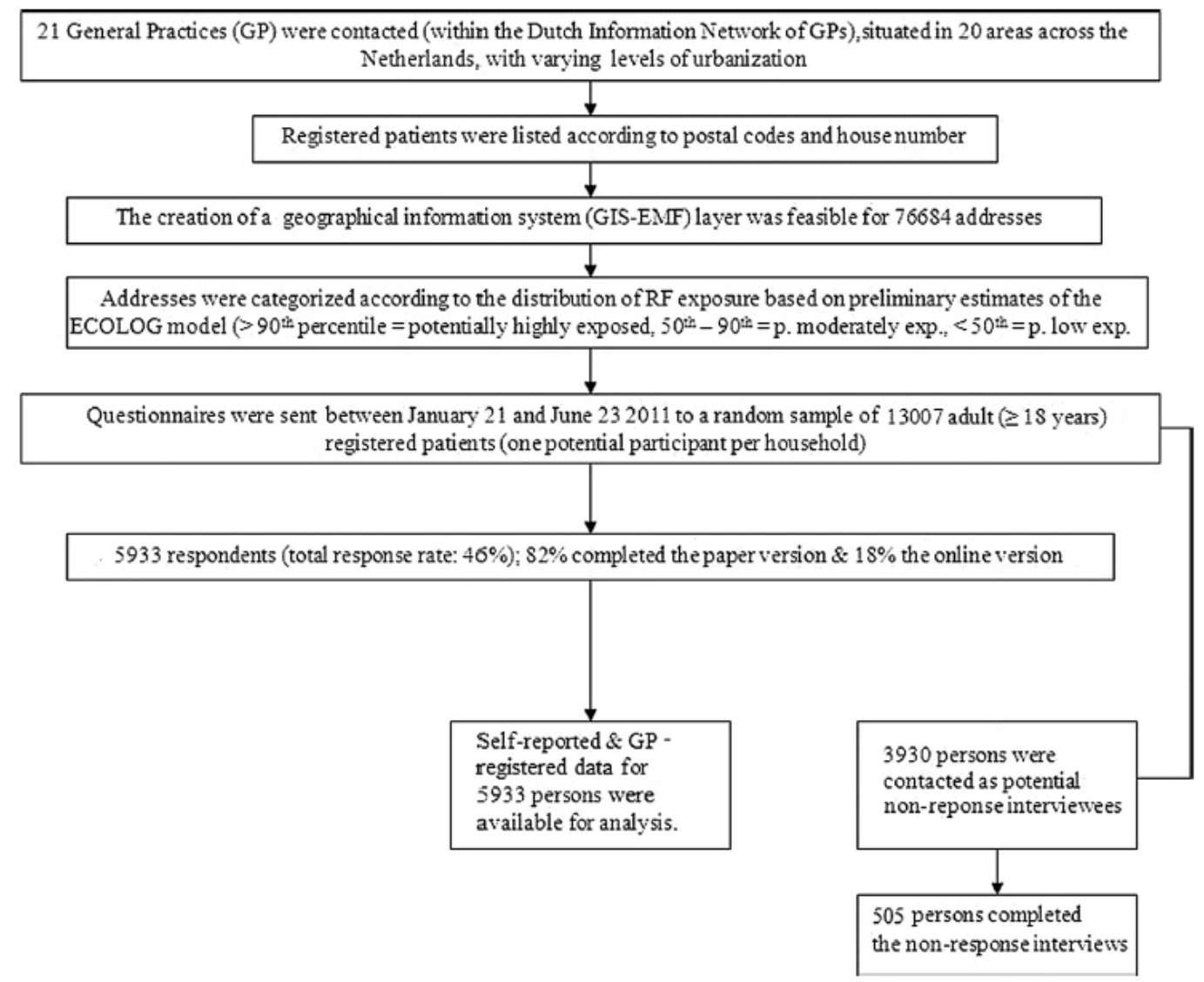

Table 1: Overview of demographic, residential, lifestyle and symptom characteristics of the sample (valid cases). ${ }^{\mathrm{a}}$

\begin{tabular}{||c||c|}
\hline \multicolumn{1}{|c|}{ Characteristic } & \multicolumn{1}{c|}{$\begin{array}{c}\text { Analytic sample } \\
(\boldsymbol{n}=\mathbf{5 9 3 3})\end{array}$} \\
\hline Demographic characteristics & \\
\hline Age (\%) & 5.8 \\
\hline \hline $18-24$ & 30.4 \\
\hline \hline $25-44$ & 39.5 \\
\hline \hline $45-64$ & 13.0 \\
\hline \hline $65-74$ & 11.1 \\
\hline \hline $75+$ & $52.2(17.3)$ \\
\hline Mean age (SD) & \\
\hline
\end{tabular}


Baliatsas, C., Bolte, J., Yzermans, J., Kelfkens, G., Hooiveld, M., Lebret, E., Kamp, I. van. Actuał and perceived exposure to electromagnetic fields and non-specific physical symptoms: an epidemiological study based on self-reported data and electronic medical records. Internationalf Journal of Hygiene and Environmental Health: 2015

\begin{tabular}{|c|c|}
\hline Characteristic & $\begin{array}{c}\text { Analytic sample } \\
\quad(n=5933) \\
\end{array}$ \\
\hline Female gender (\%) & 58.4 \\
\hline \multicolumn{2}{|l|}{ Education $^{\mathrm{b}}(\%)$} \\
\hline Lower & 24.0 \\
\hline Middle & 44.3 \\
\hline Higher & 31.6 \\
\hline Foreign background (\%) & 12.6 \\
\hline \multicolumn{2}{|l|}{ Residential characteristics } \\
\hline \multicolumn{2}{|l|}{ Home ownership status (\%) } \\
\hline Owned & 65.3 \\
\hline Rented & 34.7 \\
\hline \multicolumn{2}{|l|}{ Degree of urbanization (\%) } \\
\hline Extremely urbanized & 22.9 \\
\hline Strongly urbanized & 24.6 \\
\hline Moderately urbanized & 16.3 \\
\hline Hardly urbanized & 18.7 \\
\hline \begin{tabular}{|l|} 
Not urbanized \\
\end{tabular} & 17.6 \\
\hline \multicolumn{2}{|l|}{ Lifestyle characteristics } \\
\hline \multicolumn{2}{|l|}{ Smoking habits (\%) } \\
\hline Never & 43.0 \\
\hline In the past & 37.0 \\
\hline \begin{tabular}{|l|} 
Yes, currently \\
\end{tabular} & 20.0 \\
\hline $\begin{array}{l}\text { Alcohol and/or substance abuse (> } 4 \text { months) } \\
(\%)\end{array}$ & 2.4 \\
\hline \multicolumn{2}{|l|}{ Symptom characteristics } \\
\hline Number of symptoms mean score (SD) & $5.3(4.0)$ \\
\hline Duration of symptoms mean score (SD) & $12.8(12.5)$ \\
\hline (Low) sleep quality (SD) & $2.3(2.6)$ \\
\hline Prevalence of GP-registered NSPS (\%) & 36.5 \\
\hline
\end{tabular}

A. Missing values (\% of the total sample): education (4.1), foreign background (1.6), home ownership status (1.0), smoking habits (0.3), alcohol and/or substance abuse (6.1), number of NSPS (5.9), duration of NSPS (7.4), sleep quality (8.1); no missing values for age, gender and degree of urbanization, GP-registered NSPS.

B. Lower: no education or primary school or lower secondary education; middle: intermediate vocational or intermediate general secondary or higher 
Baliatsas, C., Bolte, J., Yzermans, J., Kelfkens, G., Hooiveld, M., Lebret, E., Kamp, I. van. Actuah and perceived exposure to electromagnetic fields and non-specific physical symptoms: an epidemiological study based on self-reported data and electronic medical records. Internationalf Journal of Hygiene and Environmental Health: 2015

general secondary education; higher: higher vocational or university education. Abbreviation: SD, standard deviation.

Table 2. Levels of modeled exposure to RF-EMF (V/m) in the analytic sample.

\begin{tabular}{|c|c|c|c|c|}
\hline \multirow{2}{*}{ RF band } & \multicolumn{4}{|c|}{ Exposure levels } \\
\hline & Sample & Range & $\begin{array}{l}\text { Mean } \\
\text { (SD) }\end{array}$ & $\begin{array}{c}\text { 90th } \\
\text { percentile }\end{array}$ \\
\hline GSM900 & 4266 & $\begin{array}{l}0.02- \\
0.29\end{array}$ & $\begin{array}{l}0.06 \\
(0.06)\end{array}$ & 0.08 \\
\hline GSM1800 & 4344 & $\begin{array}{l}0.04- \\
0.46\end{array}$ & $\begin{array}{l}0.07 \\
(0.08)\end{array}$ & 0.09 \\
\hline DECT & 5447 & $\begin{array}{l}0.02- \\
0.25\end{array}$ & $0.1(0.08)$ & 0.13 \\
\hline Uplink & 4139 & $\begin{array}{l}0.09- \\
0.37\end{array}$ & $\begin{array}{l}0.13 \\
(0.12)\end{array}$ & 0.18 \\
\hline Downlink & 4344 & $\begin{array}{l}0.05- \\
0.56\end{array}$ & $\begin{array}{l}0.09 \\
0.11)\end{array}$ & 0.13 \\
\hline Radio/TV & 4392 & $\begin{array}{l}0.04- \\
0.49\end{array}$ & $\begin{array}{l}0.05 \\
(0.07)\end{array}$ & 0.07 \\
\hline $\begin{array}{l}\text { Exposure to base stations at } \\
\text { home }\end{array}$ & 4536 & $\begin{array}{l}0.00- \\
1.09\end{array}$ & $0.12(0.2)$ & 0.22 \\
\hline
\end{tabular}

Abbreviation: SD, standard deviation.

Table 3. Association (regression coefficients and ORs) ${ }^{\mathrm{a}}$ between modeled RF-EMF (per frequency band) and perceived EMF exposure and NSPS, based on self-reported scores and GP-registered prevalence (significant associations based on $p$ values in bold).

\begin{tabular}{|c|c|c|c|c|}
\hline \multirow{2}{*}{$\begin{array}{l}\text { RF-EMF } \\
\text { exposure }\end{array}$} & \multicolumn{3}{|c|}{ B coefficient $\left(95 \%\right.$ CI) ${ }^{b}$} & \multirow{2}{*}{$\begin{array}{c}\text { OR (95\% } \\
\text { CI) }\end{array}$} \\
\hline & $\begin{array}{c}\text { Number of } \\
\text { self-reported } \\
\text { NSPS }\end{array}$ & $\begin{array}{c}\text { Duration of } \\
\text { self-reported } \\
\text { NSPS }\end{array}$ & $\begin{array}{c}\text { Sleep } \\
\text { quality }\end{array}$ & \\
\hline GSM900 & $\begin{array}{l}0.07(-0.05 \text { to } \\
0.2)\end{array}$ & $\begin{array}{l}0.22(-0.17 \text { to } \\
0.61)\end{array}$ & $\begin{array}{l}0.01(-0.08 \\
\text { to } 0.09)\end{array}$ & \begin{tabular}{|l}
$1.00(0.92-$ \\
$1.07)$
\end{tabular} \\
\hline Perceived EMF & $\begin{array}{l}0.07(0.05- \\
0.09)^{\ddagger}\end{array}$ & $\begin{array}{l}0.23(0.17- \\
0.28)^{\ddagger}\end{array}$ & $\begin{array}{l}0.02(0.01- \\
0.03)^{\dagger}\end{array}$ & $\begin{array}{l}1.01(1.003- \\
1.02)^{*}\end{array}$ \\
\hline GSM1800 & $\begin{array}{l}0.06(-0.01 \text { to } \\
0.13)\end{array}$ & $\begin{array}{l}0.21(-0.004 \text { to } \\
0.42)\end{array}$ & $\begin{array}{l}0.01(-0.04 \\
\text { to } 0.05)\end{array}$ & $\begin{array}{l}1.01(0.98- \\
1.05)\end{array}$ \\
\hline
\end{tabular}


Baliatsas, C., Bolte, J., Yzermans, J., Kelfkens, G., Hooiveld, M., Lebret, E., Kamp, I. van. Actuał and perceived exposure to electromagnetic fields and non-specific physical symptoms: an epidemiological study based on self-reported data and electronic medical records. Internationalf Journal of Hygiene and Environmental Health: 2015

\begin{tabular}{|c|c|c|c|c|}
\hline \multirow{2}{*}{$\begin{array}{l}\text { RF-EMF } \\
\text { exposure }\end{array}$} & \multicolumn{3}{|c|}{ B coefficient $\left(95 \%\right.$ CI) ${ }^{b}$} & \multirow{2}{*}{$\begin{array}{c}\text { OR (95\% } \\
\text { CI) }\end{array}$} \\
\hline & $\begin{array}{c}\text { Number of } \\
\text { self-reported } \\
\text { NSPS } \\
\end{array}$ & $\begin{array}{c}\text { Duration of } \\
\text { self-reported } \\
\text { NSPS }\end{array}$ & $\begin{array}{c}\text { Sleep } \\
\text { quality }\end{array}$ & \\
\hline Perceived EMF & $\begin{array}{l}0.07(0.06- \\
0.09)^{\ddagger}\end{array}$ & $\begin{array}{l}0.23(0.18- \\
0.29)^{\ddagger}\end{array}$ & $\begin{array}{l}0.02(0.01- \\
0.03)^{\ddagger}\end{array}$ & \begin{tabular}{|l}
$1.01(1.004-$ \\
$1.02)^{\dagger}$
\end{tabular} \\
\hline DECT & $\begin{array}{l}0.04(-0.02 \text { to } \\
0.11)\end{array}$ & \begin{tabular}{|l}
$-0.03(-0.24$ to \\
$0.17)$
\end{tabular} & $\begin{array}{l}-0.003 \\
(-0.05 \text { to } \\
0.04)\end{array}$ & $\begin{array}{l}0.99(0.95- \\
1.03)\end{array}$ \\
\hline Perceived EMF & $\begin{array}{l}0.06(0.05- \\
0.08)^{\ddagger}\end{array}$ & $0.2(0.15-0.25)^{\ddagger}$ & $\begin{array}{l}0.02(0.01- \\
0.03)^{\dagger}\end{array}$ & $\begin{array}{l}.01(1.002- \\
1.02)^{*}\end{array}$ \\
\hline Uplink & $\begin{array}{l}-0.001(-0.04 \\
\text { to } 0.03)\end{array}$ & $\begin{array}{l}-0.02(-0.14 \text { to } \\
0.09)\end{array}$ & $\begin{array}{l}0.01(-0.01 \\
\text { to } 0.04)\end{array}$ & \begin{tabular}{|l}
$1.00(0.98-$ \\
$1.02)$
\end{tabular} \\
\hline Perceived EMF & $\begin{array}{l}0.06(0.04- \\
0.08)^{\ddagger}\end{array}$ & $0.2(0.13-0.26)^{\ddagger}$ & $\begin{array}{l}0.02 \\
(0.002- \\
0.03)^{*}\end{array}$ & $\begin{array}{l}1.01(0.99- \\
1.02)\end{array}$ \\
\hline Downlink & $\begin{array}{l}0.02(-0.01 \text { to } \\
0.06)\end{array}$ & $\mid \begin{array}{l}0.07(-0.05 \text { to } \\
0.19)\end{array}$ & $\begin{array}{l}0.002 \\
(-0.02 \text { to } \\
0.03)\end{array}$ & $\begin{array}{l}1.00(0.97- \\
1.02)\end{array}$ \\
\hline Perceived EMF & $\begin{array}{l}0.07(0.06- \\
0.09)^{\ddagger}\end{array}$ & $\begin{array}{l}0.23(0.18- \\
0.29)^{\ddagger}\end{array}$ & $\begin{array}{l}0.02(0.01- \\
0.03)^{\ddagger}\end{array}$ & $\begin{array}{l}1.01(1.004- \\
1.02)^{\dagger}\end{array}$ \\
\hline Radio/TV & \begin{tabular}{|l}
$-0.07(-0.15$ to \\
$0.01)$
\end{tabular} & $\begin{array}{l}-0.21(-0.46 \text { to } \\
0.04)\end{array}$ & \begin{tabular}{|l}
-0.03 \\
$(-0.09$ to \\
$0.02)$
\end{tabular} & $\begin{array}{l}0.96(0.9- \\
1.02)\end{array}$ \\
\hline Perceived EMF & $\begin{array}{l}0.06(0.04- \\
0.08)^{\ddagger}\end{array}$ & $0.2(0.14-0.27)^{\ddagger}$ & $\begin{array}{l}0.01 \\
(0.002- \\
0.03)^{*}\end{array}$ & $\mid \begin{array}{l}1.01(0.99- \\
1.02)\end{array}$ \\
\hline $\begin{array}{l}\text { Exposure to } \\
\text { base stations at } \\
\text { home }\end{array}$ & $\begin{array}{l}0.00(-0.001 \text { to } \\
0.001)\end{array}$ & $\begin{array}{l}0.001(-0.002 \\
\text { to } 0.005)\end{array}$ & $\begin{array}{l}0.00 \\
(-0.001 \text { to } \\
0.001)\end{array}$ & $\mid \begin{array}{l}1.00(0.99- \\
1.00)\end{array}$ \\
\hline Perceived EMF & $\begin{array}{l}0.07(0.06- \\
0.09)^{\ddagger}\end{array}$ & $\begin{array}{l}0.23(0.17- \\
0.28)\end{array}$ & $\begin{array}{l}0.02(0.01- \\
0.03)^{\dagger}\end{array}$ & \begin{tabular}{|l}
$1.01(1.004-$ \\
$1.02)^{\dagger}$
\end{tabular} \\
\hline
\end{tabular}

Abbreviations: OR, odds ratios; CI, confidence intervals; NSPS, non-specific physical symptoms; GP, general practice.

All models were adjusted for age, gender, education, foreign background, rented home, degree of urbanization, smoking habits, alcohol and/or substance abuse. Unstandardized regression coefficient.

$* p<0.05$.

$\dagger p<0.01$.

$\ddagger p<0.001$. 
Baliatsas, C., Bolte, J., Yzermans, J., Kelfkens, G., Hooiveld, M., Lebret, E., Kamp, I. van. Actuałh and perceived exposure to electromagnetic fields and non-specific physical symptoms: an epidemiological study based on self-reported data and electronic medical records. Internationalf Journal of Hygiene and Environmental Health: 2015

Fig. 2. Percentage (\%) of "high” or "extremely high” worry about potential health effects from different EMF sources among participants with IEI-EMF $(n=202)$ and the totalstudy sample $(\mathrm{n}=5933)$.

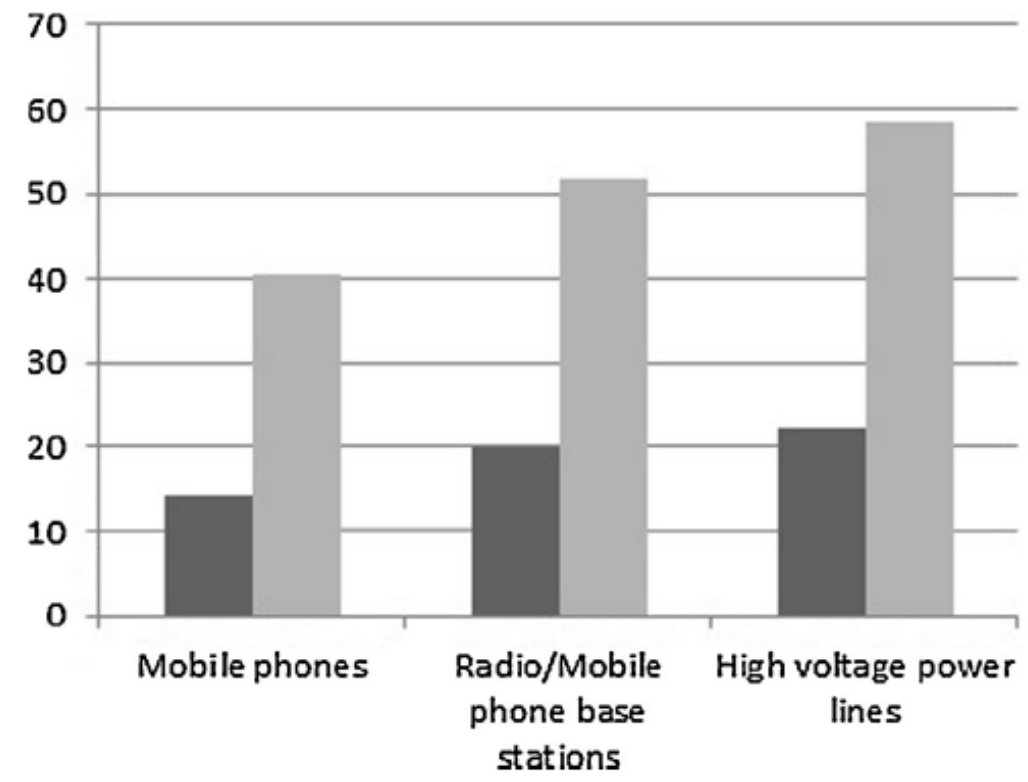

Total sample

IEI-EMF group

Table 4. Association (regression coefficients and ORs) ${ }^{\mathrm{a}}$ between distance to and use of ELF-MF sources and NSPS based on self-reported scores and GP-registered prevalence (significant associations based on $p$ values in bold).

\begin{tabular}{|c|c|c|c|c|}
\hline \multirow[t]{2}{*}{ Source/appliance } & \multicolumn{3}{|c|}{ B coefficient $(95 \% \text { CI })^{b}$} & \multirow{2}{*}{$\begin{array}{c}\text { OR }(95 \% \\
\text { CI) }\end{array}$} \\
\hline & \begin{tabular}{|c|} 
Number of \\
self-reported \\
NSPS \\
\end{tabular} & \begin{tabular}{|c|} 
Duration of \\
self-reported \\
NSPS \\
\end{tabular} & $\begin{array}{l}\text { Sleep } \\
\text { quality }\end{array}$ & \\
\hline \multicolumn{5}{|c|}{ Distance to power lines } \\
\hline$>200 \mathrm{~m}(n=5855)$ & Ref. & Ref. & Ref. & 1 \\
\hline$\leq 200 \mathrm{~m}(n=78)$ & $\mid \begin{array}{l}-0.31(-1.23 \\
\text { to } 0.61)\end{array}$ & $\begin{array}{l}0.27(-2.63 \text { to } \\
3.17)\end{array}$ & \begin{tabular}{|l}
-0.26 \\
$(-0.89$ to \\
$0.38)$ \\
\end{tabular} & $\begin{array}{l}1.25(0.74- \\
2.1)\end{array}$ \\
\hline Perceived EMF & $\mid \begin{array}{l}0.07(0.05- \\
0.08)^{\ddagger}\end{array}$ & $\begin{array}{l}0.21(0.16- \\
0.26)^{\ddagger}\end{array}$ & \begin{tabular}{|l|}
0.02 \\
$(0.01-$ \\
$0.03)^{\ddagger}$ \\
\end{tabular} & $\begin{array}{l}1.01(1.002- \\
1.02)^{*}\end{array}$ \\
\hline \multicolumn{5}{|l|}{ Electric alarm clock } \\
\hline$>50 \mathrm{~cm}(n=2960)$ & Ref. & Ref. & Ref. & 1 \\
\hline$\leq 50 \mathrm{~cm}(n=2833)$ & \begin{tabular}{|l}
$-0.08(-0.29$ \\
to 0.13$)$
\end{tabular} & \begin{tabular}{|l}
$-0.05(-0.71$ \\
to 0.61$)$
\end{tabular} & \begin{tabular}{|l}
$0.04(-0.1$ \\
to 0.19$)$
\end{tabular} & \begin{tabular}{|l|}
$0.93(0.82-$ \\
$1.05)$
\end{tabular} \\
\hline
\end{tabular}


Baliatsas, C., Bolte, J., Yzermans, J., Kelfkens, G., Hooiveld, M., Lebret, E., Kamp, I. van. Actuah and perceived exposure to electromagnetic fields and non-specific physical symptoms: an epidemiological study based on self-reported data and electronic medical records. Internationalf Journal of Hygiene and Environmental Health: 2015

\begin{tabular}{|c|c|c|c|c|}
\hline \multirow{2}{*}{ Source/appliance } & \multicolumn{3}{|c|}{ B coefficient $(95 \% \mathrm{CI})^{\mathrm{b}}$} & \multirow{2}{*}{$\begin{array}{c}\text { OR (95\% } \\
\text { CI) }\end{array}$} \\
\hline & \begin{tabular}{||c|} 
Number of \\
self-reported \\
NSPS \\
\end{tabular} & \begin{tabular}{|c|} 
Duration of \\
self-reported \\
NSPS \\
\end{tabular} & $\begin{array}{c}\text { Sleep } \\
\text { quality }\end{array}$ & \\
\hline Perceived EMF & $\mid \begin{array}{l}0.07(0.05- \\
0.08)^{\ddagger}\end{array}$ & $\begin{array}{l}0.21(0.16- \\
0.26)^{\ddagger}\end{array}$ & \begin{tabular}{|l}
0.02 \\
$(0.01-$ \\
$0.03)^{\ddagger}$ \\
\end{tabular} & $\begin{array}{l}1.01(1.003- \\
1.02)^{*}\end{array}$ \\
\hline \multicolumn{5}{|l|}{ Electric charger } \\
\hline$>50 \mathrm{~cm}(n=4952)$ & Ref. & Ref. & Ref. & 1 \\
\hline$\leq 50 \mathrm{~cm}(n=946)$ & $\mid \begin{array}{l}0.47(0.18- \\
0.75)^{\dagger}\end{array}$ & $\begin{array}{l}1.67(0.79- \\
2.56)^{\ddagger}\end{array}$ & $\mid \begin{array}{l}0.07 \\
(-0.13 \text { to } \\
0.27)\end{array}$ & $\begin{array}{l}1.24(1.05- \\
1.46)^{\dagger}\end{array}$ \\
\hline Perceived EMF & $\mid \begin{array}{l}0.06(0.05- \\
0.08)^{\ddagger}\end{array}$ & $\begin{array}{l}0.2(0.15- \\
0.25)^{\ddagger}\end{array}$ & $\begin{array}{l}0.02 \\
(0.01- \\
0.03)^{\ddagger} \\
\end{array}$ & $\begin{array}{l}1.01(1.002- \\
1.02)^{*}\end{array}$ \\
\hline \multicolumn{5}{|l|}{ Electric oven } \\
\hline $\begin{array}{l}\text { No use at all } \\
(n=1631)\end{array}$ & Ref. & Ref. & Ref. & 1 \\
\hline Use $(n=4147)$ & $\mid \begin{array}{l}0.13(-0.11 \text { to } \\
0.38)\end{array}$ & $\begin{array}{l}0.08(-0.68 \text { to } \\
0.85)\end{array}$ & \begin{tabular}{|l}
-0.02 \\
$(-0.19$ to \\
$0.15)$
\end{tabular} & $\begin{array}{l}0.95(0.82- \\
1.09)\end{array}$ \\
\hline Perceived EMF & $\mid \begin{array}{l}0.07(0.05- \\
0.08)^{\ddagger}\end{array}$ & $\begin{array}{l}0.21(0.16- \\
0.26)^{\ddagger}\end{array}$ & $\begin{array}{l}0.02 \\
(0.01- \\
0.03)^{\ddagger} \\
\end{array}$ & $\begin{array}{l}1.01(1.002- \\
1.02)^{*}\end{array}$ \\
\hline \multicolumn{5}{|l|}{ Induction hob } \\
\hline $\begin{array}{l}\text { No use at all } \\
(n=5145)\end{array}$ & Ref. & Ref. & Ref. & 1 \\
\hline Use $(n=547)$ & $\mid \begin{array}{l}-0.1(-0.45 \text { to } \\
0.25)\end{array}$ & \begin{tabular}{|l}
$-0.27(-1.38$ \\
to 0.83$)$
\end{tabular} & \begin{tabular}{|l}
-0.11 \\
$(-0.36$ to \\
$0.13)$
\end{tabular} & $1.34(1.1-$ \\
\hline Perceived EMF & $\mid \begin{array}{l}0.07(0.05- \\
0.08)^{\ddagger}\end{array}$ & $\begin{array}{l}0.21(0.16- \\
0.26)^{\ddagger}\end{array}$ & $\begin{array}{l}0.02 \\
(0.01- \\
0.03)^{\ddagger} \\
\end{array}$ & $\begin{array}{l}1.01(1.003- \\
1.02)^{*}\end{array}$ \\
\hline \multicolumn{5}{|l|}{ Electric/ceramic hob } \\
\hline $\begin{array}{l}\text { No use at all } \\
(n=4532)\end{array}$ & Ref. & Ref. & Ref. & 1 \\
\hline Use $(n=1157)$ & $\begin{array}{l}0.06(-0.2 \text { to } \\
0.32)\end{array}$ & $\begin{array}{l}0.22(-0.59 \text { to } \\
1.05)\end{array}$ & $\begin{array}{l}0.22 \\
(0.04-0.4)^{*}\end{array}$ & $\begin{array}{l}1.11(0.96- \\
1.29)\end{array}$ \\
\hline Perceived EMF & $\begin{array}{l}0.07(0.05- \\
0.08)^{\ddagger}\end{array}$ & $\begin{array}{l}0.21(0.16- \\
0.27)^{\ddagger}\end{array}$ & $\begin{array}{l}0.02 \\
\mathbf{0 . 0 1}-\end{array}$ & $\begin{array}{l}1.01(1.003- \\
1.02)^{\dagger}\end{array}$ \\
\hline
\end{tabular}


Baliatsas, C., Bolte, J., Yzermans, J., Kelfkens, G., Hooiveld, M., Lebret, E., Kamp, I. van. Actuał and perceived exposure to electromagnetic fields and non-specific physical symptoms: an epidemiological study based on self-reported data and electronic medical records. Internationalf Journal of Hygiene and Environmental Health: 2015

\begin{tabular}{|c|c|c|c|c|}
\hline \multirow{2}{*}{ Source/appliance } & \multicolumn{3}{|c|}{ B coefficient $(95 \% \mathrm{CI})^{\mathrm{b}}$} & \multirow{2}{*}{$\begin{array}{c}\begin{array}{c}\text { OR (95\% } \\
\text { CI) }\end{array} \\
\text { GP- } \\
\text { registered } \\
\text { NSPS } \\
\end{array}$} \\
\hline & \begin{tabular}{|c} 
Number of \\
self-reported \\
NSPS
\end{tabular} & \begin{tabular}{|c} 
Duration of \\
self-reported \\
NSPS
\end{tabular} & $\begin{array}{l}\text { Sleep } \\
\text { quality }\end{array}$ & \\
\hline & & & $0.03)^{\ddagger}$ & \\
\hline \multicolumn{5}{|l|}{ PC or laptop } \\
\hline $\begin{array}{l}\text { No use at all } \\
(n=827)\end{array}$ & Ref. & Ref. & Ref. & 1 \\
\hline Use $(n=4894)$ & $\mid \begin{array}{l}-0.33(-0.71 \\
\text { to } 0.05)\end{array}$ & \begin{tabular}{|l}
$-0.74(-1.95$ \\
to 0.47$)$
\end{tabular} & $\begin{array}{l}-0.34 \\
(-0.61 \text { to } \\
-0.07)^{*}\end{array}$ & $\begin{array}{l}0.99(0.8- \\
1.23)\end{array}$ \\
\hline Perceived EMF & $\mid \begin{array}{l}0.07(0.05- \\
0.08)^{\ddagger}\end{array}$ & $\begin{array}{l}0.21(0.16- \\
0.26)^{\ddagger}\end{array}$ & $\begin{array}{l}0.02 \\
(0.01- \\
0.03)^{\ddagger} \\
\end{array}$ & $\begin{array}{l}1.01(1.002- \\
1.02)^{*}\end{array}$ \\
\hline \multicolumn{5}{|l|}{ Electric blanket } \\
\hline $\begin{array}{l}\text { No use at all } \\
(n=5076)\end{array}$ & Ref. & Ref. & Ref. & 1 \\
\hline Use $(n=654)$ & $\mid \begin{array}{l}0.58(0.24- \\
0.91)^{\dagger}\end{array}$ & $\begin{array}{l}1.35(0.29- \\
2.41)^{*}\end{array}$ & $\mid \begin{array}{l}0.02 \\
(-0.21 \text { to } \\
0.26)\end{array}$ & $\begin{array}{l}1.32(1.09- \\
1.59)^{\dagger}\end{array}$ \\
\hline Perceived EMF & $\mid \begin{array}{l}0.07(0.05- \\
0.08)^{\ddagger}\end{array}$ & $\begin{array}{l}0.21(0.16- \\
0.27)^{\ddagger}\end{array}$ & $\begin{array}{l}0.02 \\
(0.01- \\
0.03)^{\ddagger} \\
\end{array}$ & $\begin{array}{l}1.01(1.001- \\
1.02)^{*}\end{array}$ \\
\hline \multicolumn{5}{|l|}{ Vacuum cleaner } \\
\hline $\begin{array}{l}\text { No use at all } \\
(n=430)\end{array}$ & Ref. & Ref. & Ref. & 1 \\
\hline Use $(n=5291)$ & $\begin{array}{l}0.04(-0.36 \text { to } \\
0.44)\end{array}$ & \begin{tabular}{|l}
$-0.06(-1.32$ \\
to 1.2$)$
\end{tabular} & \begin{tabular}{|l}
-0.2 \\
$(-0.48$ to \\
$0.08)$
\end{tabular} & $\begin{array}{l}0.87 \text { (0.69- } \\
1.09)\end{array}$ \\
\hline Perceived EMF & $\mid \begin{array}{l}0.07(0.05- \\
0.08)^{\ddagger}\end{array}$ & $\begin{array}{l}0.21(0.16- \\
0.26)^{\ddagger}\end{array}$ & $\begin{array}{l}0.02 \\
(0.01- \\
0.03)^{\ddagger}\end{array}$ & $\begin{array}{l}1.01(1.003- \\
1.02)^{*}\end{array}$ \\
\hline
\end{tabular}

Abbreviations: OR, odds ratios; CI, confidence intervals; NSPS, non-specific physical symptoms; GP, general practice; Ref., reference category.

A Adjusted for age, gender, education, foreign background, rented home, degree of urbanization, smoking habits, alcohol and/or substance abuse, perceived EMF exposure.

B Unstandardized regression coefficient. 
Baliatsas, C., Bolte, J., Yzermans, J., Kelfkens, G., Hooiveld, M., Lebret, E., Kamp, I. van. Actuałh and perceived exposure to electromagnetic fields and non-specific physical symptoms: an epidemiological study based on self-reported data and electronic medical records. Internationalf Journal of Hygiene and Environmental Health: 2015

$* p<0.05$.

$\dagger p<0.01$.

$\ddagger p<0.001$. 
Baliatsas, C., Bolte, J., Yzermans, J., Kelfkens, G., Hooiveld, M., Lebret, E., Kamp, I. van. Actuah and perceived exposure to electromagnetic fields and non-specific physical symptoms: an epidemiological study based on self-reported data and electronic medical records. Internationalf Journal of Hygiene and Environmental Health: 2015

Table 5. Expanded regression model showing the association of perceived exposure and psychological variables with the examined health outcomes. ${ }^{a}$

\begin{tabular}{|c|c|c|c|c|}
\hline \multirow{2}{*}{ Source/appliance } & \multicolumn{3}{|c|}{$B$ coefficient $\left(95 \%\right.$ CI) ${ }^{b}$} & \multirow{2}{*}{$\begin{array}{c}\text { OR (95\% } \\
\text { CI) } \\
\text { GP- } \\
\text { registered } \\
\text { NSPS } \\
\end{array}$} \\
\hline & $\begin{array}{c}\text { Number of } \\
\text { self-reported } \\
\text { NSPS } \\
\end{array}$ & $\begin{array}{c}\text { Duration of } \\
\text { self-reported } \\
\text { NSPS } \\
\end{array}$ & $\begin{array}{c}\text { Sleep } \\
\text { quality }\end{array}$ & \\
\hline $\begin{array}{l}\text { Perceived } \\
\text { exposure }\end{array}$ & $\mid \begin{array}{l}0.07(0.05- \\
0.08)^{\ddagger}\end{array}$ & $\mid \begin{array}{l}0.21(0.16- \\
0.26)^{\ddagger}\end{array}$ & $\begin{array}{l}0.02 \\
(0.01- \\
0.03)^{\ddagger} \\
\end{array}$ & $\begin{array}{l}1.01(1.002- \\
1.02)^{*}\end{array}$ \\
\hline Control & $\mid \begin{array}{l}0.42(0.37- \\
0.48)^{\ddagger}\end{array}$ & $\begin{array}{l}1.38(1.2- \\
1.56)^{\ddagger}\end{array}$ & $\begin{array}{l}0.32 \\
(0.27- \\
0.35)^{\ddagger} \\
\end{array}$ & $\mid \begin{array}{l}1.06(1.02- \\
1.1)^{\dagger}\end{array}$ \\
\hline Avoidance & $\begin{array}{l}0.03(0.01- \\
0.06)^{*}\end{array}$ & $\begin{array}{l}0.01(-0.08 \text { to } \\
0.1)\end{array}$ & $\begin{array}{l}0.01 \\
(-0.01 \text { to } \\
0.25)\end{array}$ & $\mid \begin{array}{l}0.98(0.97- \\
1.00)\end{array}$ \\
\hline
\end{tabular}

aAdjusted for age, gender, education, foreign background, rented home, degree of urbanization, smoking habits, alcohol and/or substance abuse, sleeping close to an electric charger, induction hob use, electric/ceramic hob use, electric blanket use bUnstandardized regression coefficient.

$* p<0.05$.

$\dagger p<0.01$.

$\ddagger p<0.001$.

Table 6. :Association (ORs) ${ }^{\mathrm{a}}$ between modeled RF-EMF (per frequency band) and perceived EMF exposure and prevalence of single self-reported NSPS (significant associations based on $p$ values in bold).

\begin{tabular}{|c|c|c|c|c|c|c|c|}
\hline \multirow{2}{*}{$\begin{array}{c}\text { RF- } \\
\text { EMF } \\
\text { exposu } \\
\text { re } \\
\end{array}$} & \multicolumn{7}{|c|}{ OR (95\% CI) } \\
\hline & $\begin{array}{c}\text { Heada } \\
\text { che }\end{array}$ & \begin{tabular}{|c} 
Dizzin \\
ess or \\
feeling \\
light- \\
heade \\
d \\
\end{tabular} & $\begin{array}{c}\text { Fatigue/tire } \\
\text { dness }\end{array}$ & $\mid \begin{array}{c}\text { Memory } \\
\text { or } \\
\text { concentra } \\
\text { tion } \\
\text { problems }\end{array}$ & \begin{tabular}{|} 
Skin \\
sympto \\
ms
\end{tabular} & $\mid \begin{array}{c}\text { Heart } \\
\text { palpitati } \\
\text { ons }\end{array}$ & $\begin{array}{c}\text { Ear } \\
\text { sympto } \\
\text { ms }\end{array}$ \\
\hline $\begin{array}{l}\text { GSM9 } \\
00\end{array}$ & \begin{tabular}{|l}
1.05 \\
$(0.97-$ \\
$1.13)$ \\
\end{tabular} & $\begin{array}{l}0.95 \\
(0.86- \\
1.04)\end{array}$ & $\begin{array}{l}1.00(0.93- \\
1.08)\end{array}$ & $\begin{array}{l}1.00 \\
(0.92- \\
1.09)\end{array}$ & $\begin{array}{l}1.07 \\
(0.99- \\
1.15)\end{array}$ & $\left(\begin{array}{l}0.91 \\
(0.8- \\
1.03)\end{array}\right.$ & $\begin{array}{l}0.96 \\
(0.86- \\
1.08)\end{array}$ \\
\hline
\end{tabular}


Baliatsas, C., Bolte, J., Yzermans, J., Kelfkens, G., Hooiveld, M., Lebret, E., Kamp, I. van. Actuah and perceived exposure to electromagnetic fields and non-specific physical symptoms: an epidemiological study based on self-reported data and electronic medical records. Internatjonalf Journal of Hygiene and Environmental Health: 2015

\begin{tabular}{|c|c|c|c|c|c|c|c|}
\hline \multirow{3}{*}{\begin{tabular}{|c|} 
RF- \\
EMF \\
exposu \\
re \\
\end{tabular}} & \multicolumn{7}{|c|}{ OR (95\% CI) } \\
\hline & & & & & & & \\
\hline & $\begin{array}{c}\text { Heada } \\
\text { che }\end{array}$ & \begin{tabular}{|c} 
Dizzin \\
ess or \\
feeling \\
light- \\
heade \\
d \\
\end{tabular} & $\begin{array}{c}\text { Fatigue/tire } \\
\text { dness }\end{array}$ & $\begin{array}{c}\text { Memory } \\
\text { or } \\
\text { concentra } \\
\text { tion } \\
\text { problems }\end{array}$ & $\mid \begin{array}{c}\text { Skin } \\
\text { sympto } \\
\text { ms }\end{array}$ & $\mid \begin{array}{c}\text { Heart } \\
\text { palpitati } \\
\text { ons }\end{array}$ & $\begin{array}{c}\text { Ear } \\
\text { sympto } \\
\text { ms }\end{array}$ \\
\hline \begin{tabular}{|l} 
Perceiv \\
ed \\
EMF \\
\end{tabular} & $\begin{array}{l}1.02 \\
(1.01- \\
1.03)^{\ddagger} \\
\end{array}$ & $\begin{array}{l}1.02 \\
(1.01- \\
1.04)^{\ddagger} \\
\end{array}$ & $\begin{array}{l}1.04(1.03- \\
1.05)^{\ddagger}\end{array}$ & $\begin{array}{l}1.02 \\
(1.01- \\
1.04)^{\ddagger} \\
\end{array}$ & $\begin{array}{l}1.02 \\
(1.01- \\
1.03)^{\dagger} \\
\end{array}$ & $\begin{array}{l}1.02 \\
(1.01- \\
1.04)^{\dagger} \\
\end{array}$ & \begin{tabular}{|l|}
1.02 \\
$(1.004-$ \\
$1.03)^{*}$
\end{tabular} \\
\hline $\begin{array}{l}\text { GSM1 } \\
800\end{array}$ & $\begin{array}{l}1.04 \\
(0.99- \\
1.09) \\
\end{array}$ & $\begin{array}{l}1.00 \\
(0.95- \\
1.04) \\
\end{array}$ & $\begin{array}{l}1.03(0.98- \\
1.09)\end{array}$ & $\begin{array}{l}1.01 \\
(0.97- \\
1.06) \\
\end{array}$ & $\begin{array}{l}1.02 \\
(0.98- \\
1.06) \\
\end{array}$ & $\begin{array}{l}0.98 \\
(0.93- \\
1.05) \\
\end{array}$ & \begin{tabular}{|l}
1.00 \\
$(0.94-$ \\
$1.06)$ \\
\end{tabular} \\
\hline \begin{tabular}{|l} 
Perceiv \\
ed \\
EMF \\
\end{tabular} & \begin{tabular}{|l|}
1.02 \\
$(1.01-$ \\
$1.03)^{\ddagger}$ \\
\end{tabular} & $\begin{array}{l}1.02 \\
(1.01- \\
1.04)^{\ddagger} \\
\end{array}$ & $\begin{array}{l}1.04(1.03- \\
1.05)^{\ddagger}\end{array}$ & $\begin{array}{l}1.03 \\
(1.01- \\
1.04)^{\ddagger} \\
\end{array}$ & \begin{tabular}{|l|}
1.02 \\
$(1.01-$ \\
$1.03)^{\dagger}$ \\
\end{tabular} & $\begin{array}{l}1.03 \\
(1.01- \\
1.04)^{\dagger} \\
\end{array}$ & \begin{tabular}{|l|}
1.02 \\
$(1.005-$ \\
$1.03)^{*}$
\end{tabular} \\
\hline DECT & $\begin{array}{l}0.97 \\
(0.93- \\
1.01) \\
\end{array}$ & $\begin{array}{l}0.99 \\
(0.95- \\
1.04) \\
\end{array}$ & $\begin{array}{l}0.99(0.95- \\
1.03)\end{array}$ & $\begin{array}{l}0.99 \\
(0.95- \\
1.04) \\
\end{array}$ & $\begin{array}{l}1.00 \\
(0.96- \\
1.04) \\
\end{array}$ & $\begin{array}{l}0.98 \\
(0.93- \\
1.04) \\
\end{array}$ & \begin{tabular}{|l}
1.00 \\
$(0.95-$ \\
$1.06)$ \\
\end{tabular} \\
\hline \begin{tabular}{|l} 
Perceiv \\
ed \\
EMF \\
\end{tabular} & \begin{tabular}{|l|}
1.02 \\
$(1.01-$ \\
$1.03)^{\ddagger}$ \\
\end{tabular} & $\begin{array}{l}1.02 \\
(1.01- \\
1.03)^{\ddagger} \\
\end{array}$ & $\begin{array}{l}1.03(1.02- \\
1.04)^{\ddagger}\end{array}$ & $\begin{array}{l}1.02 \\
(1.01- \\
1.03)^{\dagger} \\
\end{array}$ & \begin{tabular}{|l|}
1.01 \\
$(1.002-$ \\
$1.02)^{*}$ \\
\end{tabular} & $\begin{array}{l}1.02 \\
(1.01- \\
1.03)^{\dagger} \\
\end{array}$ & \begin{tabular}{|l|}
1.01 \\
$(0.99-$ \\
$1.03)$ \\
\end{tabular} \\
\hline Uplink & $\begin{array}{l}0.97 \\
(0.95- \\
0.99)^{*}\end{array}$ & $\begin{array}{l}0.97 \\
(0.95- \\
1.00)^{*}\end{array}$ & $\begin{array}{l}0.99(0.97- \\
1.01)\end{array}$ & $\begin{array}{l}0.99 \\
(0.97- \\
1.02) \\
\end{array}$ & $\begin{array}{l}1.00 \\
(0.98- \\
1.02) \\
\end{array}$ & $\begin{array}{l}1.00 \\
(0.97- \\
1.03)\end{array}$ & \begin{tabular}{|l}
0.99 \\
$(0.96-$ \\
$1.02)$ \\
\end{tabular} \\
\hline \begin{tabular}{|l} 
Perceiv \\
ed \\
EMF \\
\end{tabular} & $\begin{array}{l}1.02 \\
(1.01- \\
1.03)^{\dagger} \\
\end{array}$ & $\begin{array}{l}1.02 \\
(1.01- \\
1.03)^{\dagger} \\
\end{array}$ & $\begin{array}{l}1.03(1.02- \\
1.05)^{\ddagger}\end{array}$ & \begin{tabular}{|l|}
1.02 \\
$(1.004-$ \\
$1.03)^{*}$ \\
\end{tabular} & \begin{tabular}{|l|}
1.01 \\
$(1.001-$ \\
$1.03)^{*}$
\end{tabular} & $\begin{array}{l}1.02 \\
(1.01- \\
1.04)^{\dagger} \\
\end{array}$ & \begin{tabular}{|l|}
1.01 \\
$(0.99-$ \\
$1.03)$ \\
\end{tabular} \\
\hline $\begin{array}{l}\text { Downli } \\
\text { nk }\end{array}$ & \begin{tabular}{|l}
1.02 \\
$(0.99-$ \\
$1.05)$ \\
\end{tabular} & $\begin{array}{l}0.99 \\
(0.97- \\
1.02) \\
\end{array}$ & $\begin{array}{l}1.01(0.98- \\
1.04)\end{array}$ & \begin{tabular}{|l}
1.00 \\
$(0.98-$ \\
$1.03)$ \\
\end{tabular} & \begin{tabular}{|l}
1.01 \\
$(0.99-$ \\
$1.04)$ \\
\end{tabular} & $\begin{array}{l}0.99 \\
(0.95- \\
1.02) \\
\end{array}$ & \begin{tabular}{|l|}
0.99 \\
$(0.95-$ \\
$1.02)$ \\
\end{tabular} \\
\hline \begin{tabular}{|l} 
Perceiv \\
ed \\
EMF \\
\end{tabular} & \begin{tabular}{|l|}
1.02 \\
$(1.01-$ \\
$1.03)^{\ddagger}$ \\
\end{tabular} & $\begin{array}{l}1.02 \\
(1.01- \\
1.04)^{\ddagger} \\
\end{array}$ & $\begin{array}{l}1.04(1.03- \\
1.05)^{\ddagger}\end{array}$ & \begin{tabular}{|l|}
1.03 \\
$(1.01-$ \\
$1.04)^{\ddagger}$ \\
\end{tabular} & \begin{tabular}{|l|}
1.02 \\
$(1.01-$ \\
$1.03)^{\dagger}$ \\
\end{tabular} & $\begin{array}{l}1.03 \\
(1.01- \\
1.04)^{\dagger} \\
\end{array}$ & \begin{tabular}{|l|}
1.02 \\
$(1.005-$ \\
$1.03)^{*}$ \\
\end{tabular} \\
\hline $\begin{array}{l}\text { Radio/ } \\
\text { TV }\end{array}$ & \begin{tabular}{|l}
0.98 \\
$(0.93-$ \\
$1.02)$ \\
\end{tabular} & $\begin{array}{l}1.02 \\
(0.97- \\
1.08) \\
\end{array}$ & $\begin{array}{l}0.96(0.92- \\
1.01)\end{array}$ & $\begin{array}{l}0.99 \\
(0.94- \\
1.04) \\
\end{array}$ & \begin{tabular}{|l}
1.00 \\
$(0.95-$ \\
$1.05)$ \\
\end{tabular} & $\begin{array}{l}0.88 \\
(0.77- \\
1.02) \\
\end{array}$ & \begin{tabular}{|l|}
1.01 \\
$(0.95-$ \\
$1.07)$ \\
\end{tabular} \\
\hline \begin{tabular}{|l} 
Perceiv \\
ed \\
EMF \\
\end{tabular} & $\begin{array}{l}1.02 \\
(1.01- \\
1.03)^{\dagger}\end{array}$ & $\begin{array}{l}1.02 \\
(1.01- \\
1.03)^{\dagger}\end{array}$ & $\begin{array}{l}1.03(1.02- \\
1.05)^{\ddagger}\end{array}$ & $\begin{array}{l}1.02 \\
(1.01- \\
1.03)^{\dagger}\end{array}$ & $\begin{array}{l}1.01 \\
(0.99- \\
1.02)\end{array}$ & $\begin{array}{l}1.02 \\
(1.01- \\
1.04)^{\dagger}\end{array}$ & \begin{tabular}{|l}
1.01 \\
$(0.99-$ \\
$1.03)$ \\
\end{tabular} \\
\hline
\end{tabular}


Baliatsas, C., Bolte, J., Yzermans, J., Kelfkens, G., Hooiveld, M., Lebret, E., Kamp, I. van. Actuałh and perceived exposure to electromagnetic fields and non-specific physical symptoms: an epidemiological study based on self-reported data and electronic medical records. International Journal of Hygiene and Environmental Health: 2015

\begin{tabular}{|c|c|c|c|c|c|c|c|}
\hline \multirow{2}{*}{\begin{tabular}{|c|} 
RF- \\
EMF \\
exposu \\
re \\
\end{tabular}} & \multicolumn{7}{|c|}{ OR (95\% CI) } \\
\hline & $\begin{array}{c}\text { Heada } \\
\text { che }\end{array}$ & \begin{tabular}{|c} 
Dizzin \\
ess or \\
feeling \\
light- \\
heade \\
d \\
\end{tabular} & $\begin{array}{c}\text { Fatigue/tire } \\
\text { dness }\end{array}$ & $\mid \begin{array}{c}\text { Memory } \\
\text { or } \\
\text { concentra } \\
\text { tion } \\
\text { problems }\end{array}$ & $\mid \begin{array}{c}\text { Skin } \\
\text { sympto } \\
\text { ms }\end{array}$ & $\mid \begin{array}{c}\text { Heart } \\
\text { palpitati } \\
\text { ons }\end{array}$ & $\begin{array}{c}\text { Ear } \\
\text { sympto } \\
\text { ms }\end{array}$ \\
\hline \begin{tabular}{|l} 
Exposu \\
re to \\
base \\
stations \\
at \\
home \\
\end{tabular} & $\left(\begin{array}{l}1.00 \\
(0.99- \\
1.001)\end{array}\right.$ & $\mid \begin{array}{l}1.00 \\
(0.99- \\
1.00)\end{array}$ & $\begin{array}{l}1.00(0.99- \\
1.00)\end{array}$ & $\mid \begin{array}{l}1.00 \\
(0.99- \\
1.00)\end{array}$ & $\mid \begin{array}{l}1.00 \\
(0.99- \\
1.001)\end{array}$ & $\mid \begin{array}{l}1.00 \\
(0.99- \\
1.001)\end{array}$ & $\begin{array}{l}1.00 \\
(0.99- \\
1.00)\end{array}$ \\
\hline \begin{tabular}{|l} 
Perceiv \\
ed \\
EMF \\
\end{tabular} & \begin{tabular}{|l|}
1.02 \\
$(1.01-$ \\
$1.03)^{\ddagger}$ \\
\end{tabular} & $\begin{array}{l}1.02 \\
(1.01- \\
1.04)^{\ddagger} \\
\end{array}$ & $\begin{array}{l}1.04(1.02- \\
1.05)^{\ddagger}\end{array}$ & $\begin{array}{l}1.02 \\
(1.01- \\
1.04)^{\ddagger} \\
\end{array}$ & $\begin{array}{l}1.02 \\
(1.005- \\
1.03)^{\dagger}\end{array}$ & $\begin{array}{l}1.03 \\
(1.01- \\
1.04)^{\dagger} \\
\end{array}$ & $\begin{array}{l}1.02 \\
(1.004- \\
1.03)^{*}\end{array}$ \\
\hline
\end{tabular}

Abbreviations: OR, odds ratios; CI, confidence intervals.

aAdjusted for age, gender, education, foreign background, rented home, degree of urbanization, smoking habits, alcohol and/or substance abuse.

$* p<0.05$.

$\dagger p<0.01$.

$\ddagger p<0.001$. 
Baliatsas, C., Bolte, J., Yzermans, J., Kelfkens, G., Hooiveld, M., Lebret, E., Kamp, I. van. Actuał and perceived exposure to electromagnetic fields and non-specific physical symptoms: an epidemiological study based on self-reported data and electronic medical records. Internationalf Journal of Hygiene and Environmental Health: 2015

Table 7. Association (ORs) ${ }^{\mathrm{a}}$ between distance to and use of ELF-MF sources and prevalence of single self-reported NSPS (significant associations based on $p$ values in bold).

\begin{tabular}{|c|c|c|c|c|c|c|c|}
\hline \multirow{2}{*}{\begin{tabular}{|c|}
$\begin{array}{c}\text { Source/app } \\
\text { liance }\end{array}$ \\
\end{tabular}} & \multicolumn{7}{|c|}{ OR (95\% CI) } \\
\hline & $\begin{array}{c}\text { Heada } \\
\text { che }\end{array}$ & \begin{tabular}{||c} 
Dizzi \\
ness \\
or \\
feelin \\
g \\
light- \\
heade \\
d
\end{tabular} & $\begin{array}{c}\text { Fatigue/tir } \\
\text { edness }\end{array}$ & $\mid \begin{array}{c}\text { Memory } \\
\text { or } \\
\text { concentr } \\
\text { ation } \\
\text { problems }\end{array}$ & \begin{tabular}{||c} 
Skin \\
sympt \\
oms
\end{tabular} & $\mid \begin{array}{c}\text { Heart } \\
\text { palpitat } \\
\text { ions }\end{array}$ & \begin{tabular}{||c} 
Ear \\
sympt \\
oms
\end{tabular} \\
\hline \multicolumn{8}{|c|}{ Distance to power lines } \\
\hline$\leq 200 \mathrm{~m}$ & \begin{tabular}{|l|}
0.62 \\
$(0.34-$ \\
$1.14)$ \\
\end{tabular} & $\begin{array}{l}0.82 \\
(0.41- \\
1.65) \\
\end{array}$ & $\mid \begin{array}{l}0.96(0.57- \\
1.63)\end{array}$ & \begin{tabular}{|l}
1.08 \\
$(0.57-$ \\
$2.03)$ \\
\end{tabular} & $\begin{array}{l}0.92 \\
(0.49- \\
1.71) \\
\end{array}$ & $\begin{array}{l}1.54 \\
(0.79- \\
3.02) \\
\end{array}$ & \begin{tabular}{|l}
1.07 \\
$0.52-$ \\
$2.2)$ \\
\end{tabular} \\
\hline $\begin{array}{l}\text { Perceived } \\
\text { EMF }\end{array}$ & \begin{tabular}{|l|}
1.02 \\
$(1.01-$ \\
$1.03)^{\ddagger}$ \\
\end{tabular} & $\begin{array}{l}1.02 \\
(1.01- \\
1.03)^{\ddagger}\end{array}$ & $\mid \begin{array}{l}1.03(1.02- \\
1.04)^{\ddagger}\end{array}$ & \begin{tabular}{|l|}
1.02 \\
$(1.01-$ \\
$1.03)^{\ddagger}$ \\
\end{tabular} & \begin{tabular}{|l}
1.01 \\
$(1.001$ \\
$-1.02)$
\end{tabular} & $\begin{array}{l}1.02 \\
(1.01- \\
1.03)^{\dagger} \\
\end{array}$ & $\begin{array}{l}1.01 \\
(1.003 \\
-1.03)\end{array}$ \\
\hline \multicolumn{8}{|c|}{ Electric alarm clock } \\
\hline$\leq 50 \mathrm{~cm}$ & \begin{tabular}{|l|}
1.12 \\
$(0.99-$ \\
$1.27)$ \\
\end{tabular} & $\begin{array}{l}0.95 \\
(0.82- \\
1.09) \\
\end{array}$ & $\mid \begin{array}{l}1.11(0.98- \\
1.25)\end{array}$ & $\begin{array}{l}0.88 \\
(0.76- \\
1.01) \\
\end{array}$ & $\begin{array}{l}0.9 \\
(0.79- \\
1.03) \\
\end{array}$ & \begin{tabular}{|l}
0.97 \\
$(0.82-$ \\
$1.16)$ \\
\end{tabular} & $\begin{array}{l}0.96 \\
(0.81- \\
1.14) \\
\end{array}$ \\
\hline $\begin{array}{l}\text { Perceived } \\
\text { EMF }\end{array}$ & \begin{tabular}{|l|}
1.02 \\
$(1.01-$ \\
$1.03)^{\ddagger}$ \\
\end{tabular} & $\begin{array}{l}1.02 \\
(1.01- \\
1.03)^{\ddagger}\end{array}$ & $\mid \begin{array}{l}1.03(1.02- \\
1.04)^{\ddagger}\end{array}$ & $\begin{array}{l}1.02 \\
(1.01- \\
1.03)^{\ddagger} \\
\end{array}$ & $\begin{array}{l}1.01 \\
(0.99- \\
1.02) \\
\end{array}$ & $\begin{array}{l}1.02 \\
(1.01- \\
1.03)^{*}\end{array}$ & $\begin{array}{l}1.02 \\
(1.004 \\
-1.03)\end{array}$ \\
\hline \multicolumn{8}{|c|}{ Electric charger } \\
\hline$\leq 50 \mathrm{~cm}$ & \begin{tabular}{|l|}
1.02 \\
$(0.86-$ \\
$1.2)$ \\
\end{tabular} & $\begin{array}{l}1.12 \\
(0.93- \\
1.35)\end{array}$ & $\mid \begin{array}{l}1.36(1.15- \\
1.61)^{\ddagger}\end{array}$ & \begin{tabular}{|l}
1.14 \\
$(0.94-$ \\
$1.38)$ \\
\end{tabular} & $\begin{array}{l}1.1 \\
(0.92- \\
1.32) \\
\end{array}$ & \begin{tabular}{|l}
1.03 \\
$(0.82-$ \\
$1.3)$ \\
\end{tabular} & $\begin{array}{l}0.98 \\
(0.77- \\
1.25) \\
\end{array}$ \\
\hline $\begin{array}{l}\text { Perceived } \\
\text { EMF }\end{array}$ & \begin{tabular}{|l|}
1.02 \\
$(1.01-$ \\
$1.03)^{\ddagger}$ \\
\end{tabular} & \begin{tabular}{|l}
1.02 \\
$(1.01-$ \\
$1.03)^{\ddagger}$ \\
\end{tabular} & $\mid \begin{array}{l}1.03(1.02- \\
1.04)^{\ddagger}\end{array}$ & \begin{tabular}{|l|}
1.02 \\
$(1.01-$ \\
$1.03)^{\ddagger}$ \\
\end{tabular} & \begin{tabular}{|l|}
1.01 \\
$(1.001$ \\
$-1.02)^{*}$ \\
\end{tabular} & $\begin{array}{l}1.02 \\
(1.01- \\
1.03)^{\dagger} \\
\end{array}$ & $\begin{array}{l}1.01 \\
(1.003 \\
-1.03) \\
\end{array}$ \\
\hline \multicolumn{8}{|l|}{ Electric oven } \\
\hline $\begin{array}{l}\text { Use vs. no } \\
\text { use }\end{array}$ & \begin{tabular}{|l|}
1.06 \\
$(0.92-$ \\
$1.23)$ \\
\end{tabular} & \begin{tabular}{|l}
0.93 \\
$(0.79$ \\
$1.1)$ \\
\end{tabular} & $\begin{array}{l}1.01(0.87- \\
1.16)\end{array}$ & \begin{tabular}{|l}
0.96 \\
$(0.81-$ \\
$1.13)$
\end{tabular} & \begin{tabular}{|l}
0.99 \\
$(0.84-$ \\
$1.16)$
\end{tabular} & $\begin{array}{l}1.08 \\
(0.88- \\
1.32) \\
\end{array}$ & $\begin{array}{l}1.00 \\
(0.82- \\
1.22) \\
\end{array}$ \\
\hline $\begin{array}{l}\text { Perceived } \\
\text { EMF }\end{array}$ & \begin{tabular}{|l|}
1.02 \\
$(1.01-$ \\
$1.03)^{\ddagger}$
\end{tabular} & $\begin{array}{l}1.02 \\
(1.01- \\
1.03)^{\ddagger}\end{array}$ & $\mid \begin{array}{l}1.03(1.02- \\
1.04)^{\ddagger}\end{array}$ & $\begin{array}{l}1.02 \\
(1.01- \\
1.03)^{\ddagger}\end{array}$ & $\begin{array}{l}1.01 \\
(1.002 \\
-1.02)^{*}\end{array}$ & $\begin{array}{l}1.02 \\
(1.01- \\
1.03)^{\dagger}\end{array}$ & $\begin{array}{l}1.02 \\
(1.004 \\
-1.03)\end{array}$ \\
\hline
\end{tabular}


Baliatsas, C., Bolte, J., Yzermans, J., Kelfkens, G., Hooiveld, M., Lebret, E., Kamp, I. van. Actuah and perceived exposure to electromagnetic fields and non-specific physical symptoms: an epidemiological study based on self-reported data and electronic medical records. Internationalf

Journal of Hygiene and Environmental Health: 2015

\begin{tabular}{|c|c|c|c|c|c|c|c|}
\hline \multirow{2}{*}{\begin{tabular}{|c|}
$\begin{array}{c}\text { Source/app } \\
\text { liance }\end{array}$ \\
\end{tabular}} & \multicolumn{7}{|c|}{ OR (95\% CI) } \\
\hline & $\begin{array}{c}\text { Heada } \\
\text { che }\end{array}$ & \begin{tabular}{|c|} 
Dizzi \\
ness \\
or \\
feelin \\
g \\
light- \\
heade \\
d \\
\end{tabular} & $\begin{array}{c}\text { Fatigue/tir } \\
\text { edness }\end{array}$ & $\begin{array}{c}\text { Memory } \\
\text { or } \\
\text { concentr } \\
\text { ation } \\
\text { problems }\end{array}$ & \begin{tabular}{|c|} 
Skin \\
sympt \\
oms
\end{tabular} & $\mid \begin{array}{c}\text { Heart } \\
\text { palpitat } \\
\text { ions }\end{array}$ & \begin{tabular}{||c} 
Ear \\
sympt \\
oms
\end{tabular} \\
\hline \multicolumn{8}{|c|}{ Induction hob } \\
\hline $\begin{array}{l}\text { Use vs. no } \\
\text { use }\end{array}$ & \begin{tabular}{|l|}
1.06 \\
$(0.86-$ \\
$1.3)$ \\
\end{tabular} & \begin{tabular}{|l|}
0.93 \\
$(0.73-$ \\
$1.19)$ \\
\end{tabular} & $\mid \begin{array}{l}0.99(0.81- \\
1.21)\end{array}$ & \begin{tabular}{|l}
0.92 \\
$(0.71-$ \\
$1.18)$ \\
\end{tabular} & \begin{tabular}{|l|}
0.98 \\
$(0.77-$ \\
$1.23)$ \\
\end{tabular} & \begin{tabular}{|l}
0.85 \\
$(0.62-$ \\
$1.16)$ \\
\end{tabular} & $\begin{array}{l}0.91 \\
(0.67- \\
1.23) \\
\end{array}$ \\
\hline $\begin{array}{l}\text { Perceived } \\
\text { EMF }\end{array}$ & \begin{tabular}{|l|}
1.02 \\
$(1.01-$ \\
$1.03)^{\ddagger}$ \\
\end{tabular} & \begin{tabular}{|l|}
1.02 \\
$(1.01-$ \\
$1.03)^{\ddagger}$ \\
\end{tabular} & $\begin{array}{l}1.03(1.02- \\
1.04)^{\ddagger}\end{array}$ & \begin{tabular}{|l|}
1.02 \\
$(1.01-$ \\
$1.03)^{\ddagger}$ \\
\end{tabular} & \begin{tabular}{|l|}
1.01 \\
$(1.001$ \\
$-1.02)$
\end{tabular} & $\begin{array}{l}1.02 \\
(1.01- \\
1.03)^{\dagger} \\
\end{array}$ & $\begin{array}{l}1.02 \\
(1.004 \\
-1.03)\end{array}$ \\
\hline \multicolumn{8}{|c|}{ Electric/ceramic hob } \\
\hline $\begin{array}{l}\text { Use vs. no } \\
\text { use }\end{array}$ & \begin{tabular}{|l|}
0.98 \\
$(0.84-$ \\
$1.15)$ \\
\end{tabular} & \begin{tabular}{|l|}
0.95 \\
$(0.79-$ \\
$1.14)$ \\
\end{tabular} & $\begin{array}{l}1.01(0.86- \\
1.17)\end{array}$ & \begin{tabular}{|l}
1.11 \\
$(0.93-$ \\
$1.32)$ \\
\end{tabular} & \begin{tabular}{|l|}
1.09 \\
$(0.92-$ \\
$1.29)$ \\
\end{tabular} & $\begin{array}{l}1.14 \\
(0.93- \\
1.42) \\
\end{array}$ & $\begin{array}{l}0.98 \\
(0.79- \\
1.22) \\
\end{array}$ \\
\hline $\begin{array}{l}\text { Perceived } \\
\text { EMF }\end{array}$ & \begin{tabular}{|l|}
1.02 \\
$(1.01-$ \\
$1.03)^{\ddagger}$ \\
\end{tabular} & \begin{tabular}{|l|}
1.02 \\
$(1.01-$ \\
$1.03)^{\ddagger}$ \\
\end{tabular} & $\mid \begin{array}{l}1.03(1.02- \\
1.04)^{\ddagger}\end{array}$ & \begin{tabular}{|l|}
1.02 \\
$(1.01-$ \\
$1.03)^{\ddagger}$ \\
\end{tabular} & \begin{tabular}{|l|}
1.01 \\
$(1.001$ \\
$-1.02)$
\end{tabular} & $\begin{array}{l}1.02 \\
(1.01- \\
1.03)^{\dagger} \\
\end{array}$ & $\begin{array}{l}1.02 \\
(1.003 \\
-1.03) \\
\end{array}$ \\
\hline \multicolumn{8}{|l|}{ PC or laptop } \\
\hline $\begin{array}{l}\text { Use vs. no } \\
\text { use }\end{array}$ & \begin{tabular}{|l|}
1.23 \\
$(0.96-$ \\
$1.58)$ \\
\end{tabular} & \begin{tabular}{|l|}
0.99 \\
$(0.73-$ \\
$1.33)$ \\
\end{tabular} & $\mid \begin{array}{l}0.76(0.61- \\
0.94)^{*}\end{array}$ & \begin{tabular}{|l}
0.83 \\
$(0.65-$ \\
$1.07)$ \\
\end{tabular} & \begin{tabular}{|l|}
1.00 \\
$(0.78-$ \\
$1.28)$ \\
\end{tabular} & \begin{tabular}{|l}
0.99 \\
$(0.73-$ \\
$1.33)$ \\
\end{tabular} & $\begin{array}{l}1.13 \\
(0.85- \\
1.52) \\
\end{array}$ \\
\hline $\begin{array}{l}\text { Perceived } \\
\text { EMF }\end{array}$ & \begin{tabular}{|l|}
1.02 \\
$(1.01-$ \\
$1.03)^{\ddagger}$ \\
\end{tabular} & \begin{tabular}{|l|}
1.02 \\
$(1.01-$ \\
$1.03)^{\ddagger}$ \\
\end{tabular} & $\mid \begin{array}{l}1.03(1.02- \\
1.04)^{\ddagger}\end{array}$ & \begin{tabular}{|l|}
1.02 \\
$(1.01-$ \\
$1.03)^{\ddagger}$ \\
\end{tabular} & \begin{tabular}{|l|}
1.01 \\
$(1.001$ \\
$-1.02)$
\end{tabular} & $\begin{array}{l}1.02 \\
(1.01- \\
1.03)^{\dagger} \\
\end{array}$ & $\begin{array}{l}1.02 \\
(1.003 \\
-1.03)\end{array}$ \\
\hline \multicolumn{8}{|c|}{ Electric blanket } \\
\hline $\begin{array}{l}\text { Use vs. no } \\
\text { use }\end{array}$ & \begin{tabular}{|l}
1.1 \\
$(0.9-$ \\
$1.35)$ \\
\end{tabular} & \begin{tabular}{|l|}
1.32 \\
$(1.06-$ \\
$1.64)^{*}$ \\
\end{tabular} & $\mid \begin{array}{l}1.39(1.14- \\
1.69)^{\dagger}\end{array}$ & \begin{tabular}{|l}
1.1 \\
$(0.88-$ \\
$1.38)$ \\
\end{tabular} & \begin{tabular}{|l|}
1.19 \\
$(0.96-$ \\
$1.17)$ \\
\end{tabular} & $\begin{array}{l}1.31 \\
(1.01- \\
1.69)^{*} \\
\end{array}$ & $\begin{array}{l}1.46 \\
(1.14- \\
1.88)^{\dagger} \\
\end{array}$ \\
\hline $\begin{array}{l}\text { Perceived } \\
\text { EMF }\end{array}$ & $\begin{array}{l}1.02 \\
(1.01- \\
1.03)^{\ddagger} \\
\end{array}$ & \begin{tabular}{|l|}
1.02 \\
$(1.01-$ \\
$1.03)^{\ddagger}$ \\
\end{tabular} & $\mid \begin{array}{l}1.03(1.02- \\
1.04)^{\ddagger}\end{array}$ & $\begin{array}{l}1.02 \\
(1.01- \\
1.03)^{\ddagger} \\
\end{array}$ & \begin{tabular}{|l|}
1.01 \\
$(1.001$ \\
$-1.02)$
\end{tabular} & $\begin{array}{l}1.02 \\
(1.01- \\
1.03)^{\dagger} \\
\end{array}$ & $\begin{array}{l}1.02 \\
(1.004 \\
-1.03)^{*} \\
\end{array}$ \\
\hline \multicolumn{8}{|c|}{ Vacuum cleaner } \\
\hline $\begin{array}{l}\text { Use vs. no } \\
\text { use }\end{array}$ & \begin{tabular}{|l|}
1.14 \\
$(0.89-$ \\
$1.47)$ \\
\end{tabular} & \begin{tabular}{|l|}
1.12 \\
$(0.83-$ \\
$1.5)$ \\
\end{tabular} & $\mid \begin{array}{l}0.91(0.72- \\
1.15)\end{array}$ & $\begin{array}{l}0.92 \\
(0.7- \\
1.21)\end{array}$ & \begin{tabular}{|l|}
0.95 \\
$(0.73-$ \\
$1.23)$ \\
\end{tabular} & \begin{tabular}{|l}
0.93 \\
$(0.66-$ \\
$1.31)$
\end{tabular} & $\begin{array}{l}1.26 \\
(0.89 \\
1.79) \\
\end{array}$ \\
\hline
\end{tabular}


Baliatsas, C., Bolte, J., Yzermans, J., Kelfkens, G., Hooiveld, M., Lebret, E., Kamp, I. van. Actuałh and perceived exposure to electromagnetic fields and non-specific physical symptoms: an epidemiological study based on self-reported data and electronic medical records. Internationalf Journal of Hygiene and Environmental Health: 2015

\begin{tabular}{|c|c|c|c|c|c|c|c|}
\hline \multirow{2}{*}{\begin{tabular}{|c|}
$\begin{array}{c}\text { Source/app } \\
\text { liance }\end{array}$ \\
\end{tabular}} & \multicolumn{7}{|c|}{ OR (95\% CI) } \\
\hline & $\begin{array}{c}\text { Heada } \\
\text { che }\end{array}$ & \begin{tabular}{||c} 
Dizzi \\
ness \\
or \\
feelin \\
g \\
light- \\
heade \\
d
\end{tabular} & $\begin{array}{c}\text { Fatigue/tir } \\
\text { edness }\end{array}$ & $\begin{array}{c}\text { Memory } \\
\text { or } \\
\text { concentr } \\
\text { ation } \\
\text { problems }\end{array}$ & \begin{tabular}{||c} 
Skin \\
sympt \\
oms
\end{tabular} & $\begin{array}{c}\text { Heart } \\
\text { palpitat } \\
\text { ions }\end{array}$ & \begin{tabular}{||c} 
Ear \\
sympt \\
oms
\end{tabular} \\
\hline $\begin{array}{l}\text { Perceived } \\
\text { EMF }\end{array}$ & \begin{tabular}{|l|}
1.02 \\
$(1.01-$ \\
$1.03)^{\ddagger}$ \\
\end{tabular} & $\begin{array}{l}1.02 \\
(1.01- \\
1.03)^{\ddagger}\end{array}$ & $\mid \begin{array}{l}1.03(1.02- \\
1.04)^{\ddagger}\end{array}$ & $\begin{array}{l}1.02 \\
(1.01- \\
1.03)^{\ddagger}\end{array}$ & $\begin{array}{l}1.01 \\
(0.99- \\
1.02)\end{array}$ & $\begin{array}{l}1.02 \\
(1.01- \\
1.03)^{\dagger}\end{array}$ & $\begin{array}{l}1.02 \\
(1.003 \\
-1.03)\end{array}$ \\
\hline
\end{tabular}

Abbreviations: OR, odds ratios; CI, confidence intervals.

aAdjusted for age, gender, education, foreign background, rented home, degree of urbanization, smoking habits, alcohol and/or substance abuse.

$$
\begin{aligned}
& { }^{*} p<0.05 . \\
& \dagger p<0.01 . \\
& \ddagger p<0.001 .
\end{aligned}
$$

